\title{
TRADISI MENGHIDUPKAN MALAM NISHFU SYA'BAN DI KALANGAN MAHASISWA DI KABUPATEN JEMBER: (STUDI KRITIK SANAD, MATAN DAN LIVING SUNNAH)
}

\author{
Arbain Nurdin \\ Program Studi Pendidikan Agama Islam IAIN Jember, Jawa Timur \\ arbainnurdin86@gmail.com
}

\begin{abstract}
:
Hadis is the second source of law after the Qur'an, many values or teachings express or implied in the hadis. Among them are the hadith about nishfu Sya'ban narrated by Ibnu Majah. In this paper discussed three aspects namely the power of hadis sanad, the meaning of hadis and actualization of the hadis in the midst of society (Living sunnah). Based on the results of the research, it is found that this hadis is weak because there are among the narrators who are considered to have hadis critics as counterfeiters of hadis. While matan hadis implicitly does not conflict with syari'ah of Islam. And the practices that exist in this hadis still live in the midst of society (students) to this day.

Keywords: Tradisi, Nishfu Sya'ban, Sanad, Matan, Living Sunnab
\end{abstract}

\section{Pendahuluan}

Hadis sebagai sumber hukum Islam kedua yang berfungsi menjelaskan apa yang tidak ada di dalam ayat suci al-Qur'an, serta berfungsi sebagai contoh keteladan Nabi Muhammad SAW karena semua apa yang dikatakan, yang dilakukan dan diputuskan oleh Nabi SAW merupakan sebuah dalil yang dapat dijadikan hujjah atau pedoman dasar hukum ibadah. Salah satu hadis yang sering masyarakat jadikan pedoman dalam melakukan ibadah adalah hadis yang berkenaan dengan malam nishfu sya'ban yang diriwiyatkan oleh Ibnu Majah berikut ini:

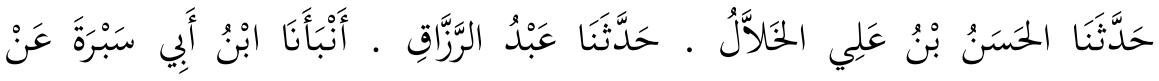

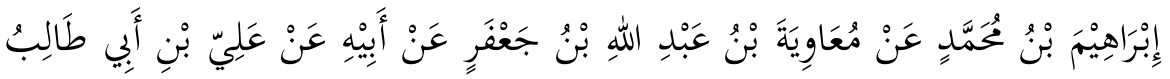




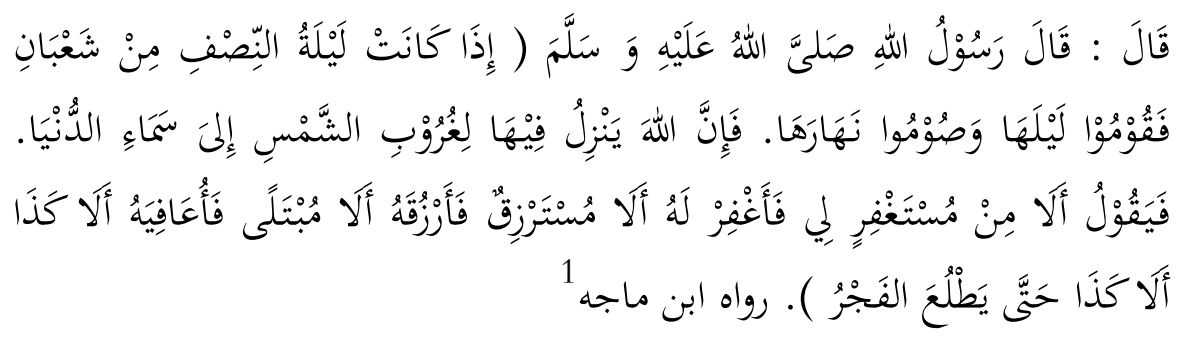

Artinya:

Menceritakan kepada kami Hasan bin Ali al-Khallal, menceritakan kepada kami Abd. Razzaq, memberitakan kepada kami Ibnu Abi Sabrah, dari Ibrahim bin Muhammad, dari Mu'awiyah bin Abdullah bin Ja'far, dari Ayahnya, dari Ali Bin Abi Tholib, ia mengatakan bahwa Rasulullah SAW bersabda: 'Bila datang malam nishfu Sya'ban maka lakukanlah Qiyam Lail dan puasa pada siang harinya, karena ketika matahari terbenam Allab turun pada malam itu ke langit dunia dan berkata, 'Adakah yang memohon ampun kepada-Ku, niscaya Aku akan mengampuninya, adakah yang memohon rezki, niscaya Aku akan memberikannya, adakah yang tertimpa penyakit, niscaya Aku akan menyembubkannya, adakah..., adakah... hingga terbit fajar."

Secara eksplisit hadis ini sangat menarik, apabila melihat isi matan yang luar biasa, karena jika datang malam nishfuSya'ban maka Allah akan mengabulkan segala macam do'a hamba-Nya di dunia. Dan Rasul pun menghidupkan malam tersebut dengan sholat malam serta berpuasa dikeesokan harinya. Namun masyarakat secara umum akan percaya hadis tersebut, karena sangat tidak bertentangan dengan ajaran agama Islam secara umum. Oleh karena setiap malam nishfuSya'ban semua umat Islam beramai-ramai menghidupkan malam tersebut dengan amalan-amalan seperti membaca surat yasin 3x dan lain sebagainya.

Pada saat bulan Sya'ban tiba, banyak amalan yang dilakukan umat muslim khususnya di Indonesia, antara lain berpuasa. Apalagi jika pertengahan bulan Sya'ban masyarakat berbondong-bondong pergi ke masjid/mushalla/langgar untuk melakukan kegiatan ibadah shalat maghrib berjamah dan dilanjutkan dengan membaca surat yasin 3x dan keesokan harinya melaksanakan ibadah puasa nishfuSya'ban. Kegiatan semacam ini terus berlangsung setiap tahunnya, dan lebih giat lagi jika diadakan sembari

${ }^{1}$ Ibn Majah, Sunan Ibnu Majah, (Kairo: Dar Al-Hadis, t.th), 
menyiapkan acara-acara lain seperti tari-tarian, serta mendatangkan da'i kondang untuk memberikan ceramah agama berkaitan dengan keistimewaan bulan Sya'ban terutama di hari nishfuSya'ban.

Asumsi dasar yang terlihat dari semua kegiatan tersebut adalah bahwa kegiatan menghidupkan malam nishfuSya'ban merupakan kegiatan yang diajarkan oleh Nabi Muhammad SAW karena di dalam hadis ada penjelasan seperti itu, akan tetapi hal itu perlu dipertanyakan kembali dikarenakan tidak semua hadis dapat dijadikan pedoman ataupun rujukan hukum ibadah. Berdasarkan fakta dan asumsi di atas, maka perlu kiranya diadakan penelitian mengenai sunnah yang hidup ditengah-tengah masyarakat khususnya berkenaan dengan amalan di malam nishfuSya'ban.

Berdasarkan fakta tersebut, menarik bagi peneliti untuk melakukan penelitian terhadap hadis tersebut baik pada sanad, matan maupun penelitian di tengah-tengah masyarakat khususnya pada kalangan mahasiswa di Kabupaten Jember.

\section{Pembahasan}

\section{Kajian Kritik Sanad}

Mengawali kajian sanad, peneliti men-takhrij hadis ${ }^{2}$ yang akan dibahas dengan melacak kata kunci sya'ban dalam al-Mu'jam al-Mufahras li Alfadz al-Hadis al-Nabany, ${ }^{3}$ ditemukan ada 35 kata sya'ban. Selanjutnya peneliti melacak kembali dalam al-Mu'jam kata kunci nishfu Sya'ban, dan peneliti menemukan ada 7 hadis dengan jalur sanad yang khusus berbicara tentang nisfbu Sya'ban.

Hadis-hadis yang berbicara tentang nisfhu Sya'ban ini ditemukan dalam berbagai kitab dengan redaksi sebagai berikut:

\section{a. Sunan Ibnu Majah (191)}

${ }^{2}$ Takbrij al-hadis adalah kegiatan penelusuran atau pencarian hadis pada berbagai kitab rujukan sebagai sumber asli dari hadis yang bersangkutan. Dalam kitab sumber tersebut dikemukakan secara lengkap sanad dan matan hadis. Lihat M. Syuhudi Ismail, Metodologi Penelitian Hadis Nabi (Cet. I; Jakarta: Bulan Bintang, 1993), 43. Terkait kegiatan takhrij al-hadis, terdapat metodologi yang bervariasi, yakni; (1) berdasarkan lafaz pertama matan hadis; (2) berdasarkan lafaz dalam matan hadis; (3) berdasarkan tema (al-mawdlu `); (4) berdasarkan periwayat pertama (al-rawi al-awwal); dan (5) berdasarkan status hadis. Lihat Abu Muhammad Abd al-Hadi bin Abd al-Qadir bin al-Hadi, Turuq Takbrij Hadis Rasulillah (Mesir: Dar al-Fikr, t.th.), 23-26. Lihat pula Mahmud Tahhan, Ushul al-Takbrij wa Dirasat al-Asanid (Beirut: al-Matba'ah al-Arabiyyah, 1978) 9-10, selanjutnya dibandingkan dengan M. Syuhudi Ismail, Metodologi Penelitian Hadis Nabi, 4649, yang menyatakan bahwa takhrij al-hadis terbagi menjadi dua, yakni bi al alfadz dan bi almawdlu'i.

${ }^{3}$ Wensinck, A.J, al-Mu'jam al-Mufahras li Alfadz al-Hadis al-Nabawi, Leiden: E.J. Brill, 1936 


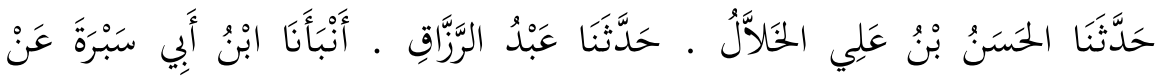

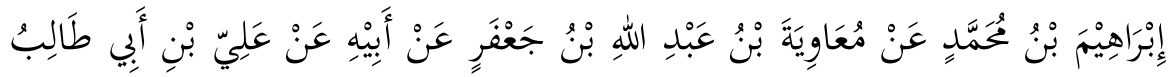

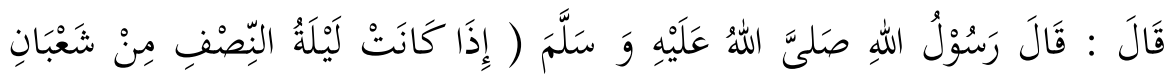

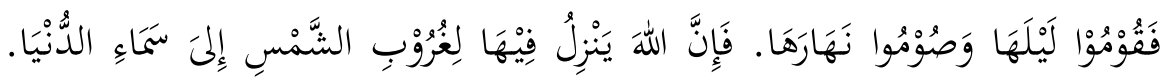

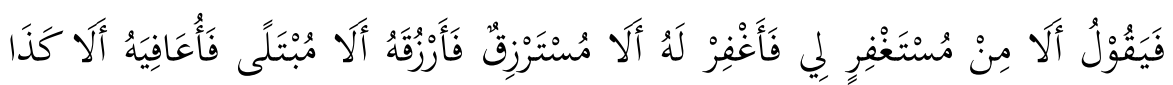

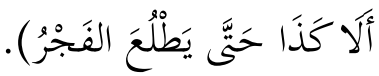

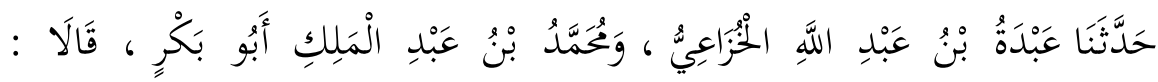

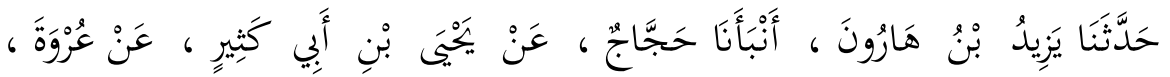

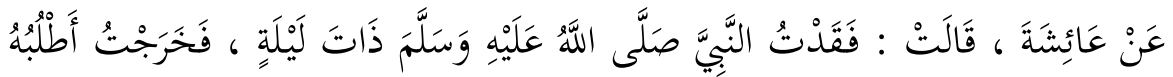

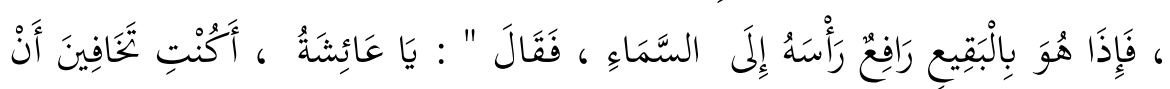

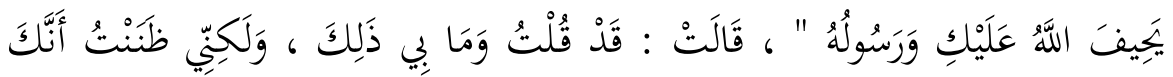

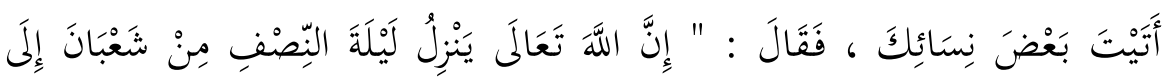

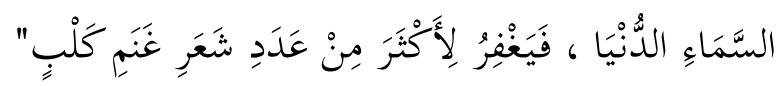

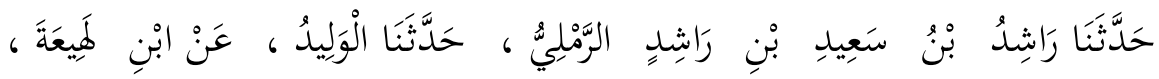

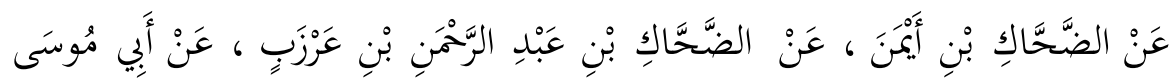

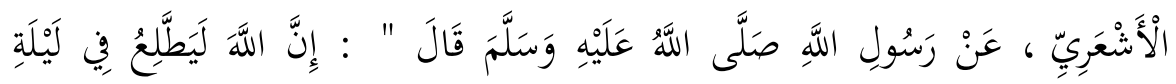

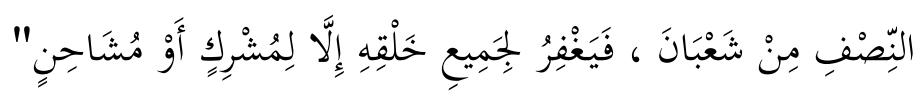

\section{b. Sunnan Tirmidzi, bab shaum, no hadis $28 / 739$}

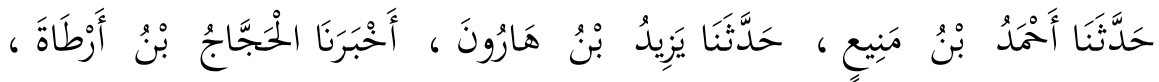

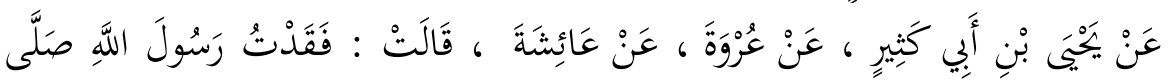




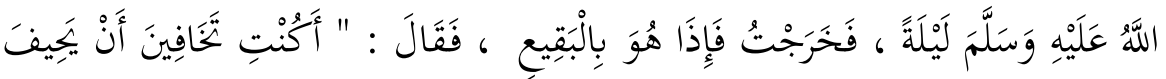

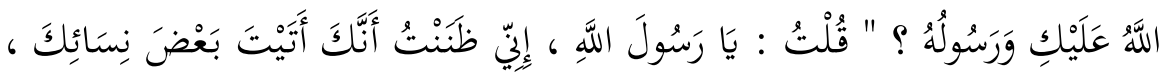

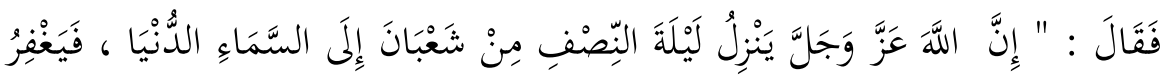

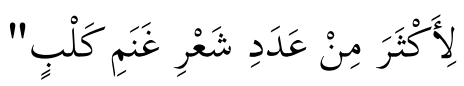

\section{c. Musnad Ahmad ibnu Hanbal (6642)}

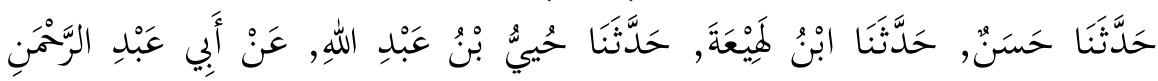

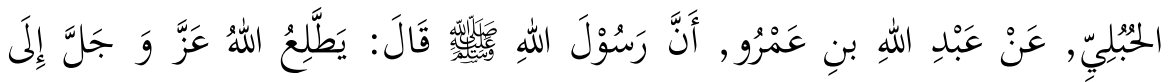

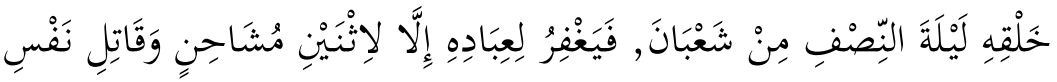

\section{d. Abdullah ibn Abdurrahman ad-Darimi, (23)}

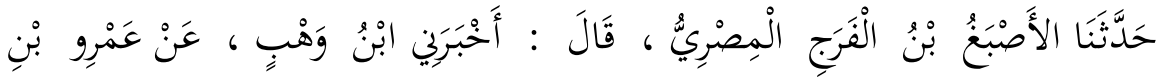

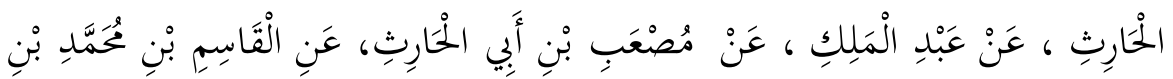

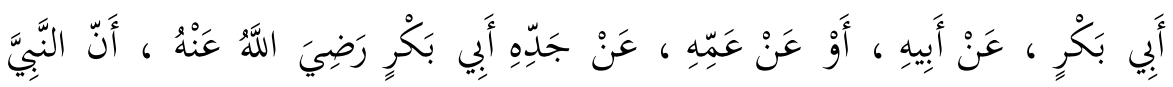

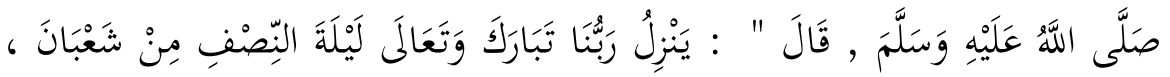

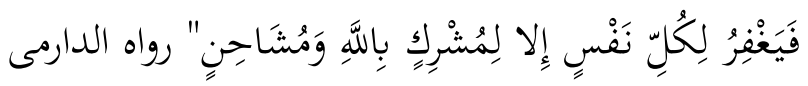

Selanjutnya peneliti akan melalukan i'tibar terhadap beberapa hadis yang memiliki kemiripan dengan hadis yang peneliti kaji yaitu hadis nisfbu Sya'ban dari periwayatan Ibnu Majah. Berdasarkan uraian jalur sanad di atas berikut akan di tampilkan skema sanad hadis dari jalur Ibn Majah, Tirmidzi, Ahmad ibn Hanbal dan Darimi: 


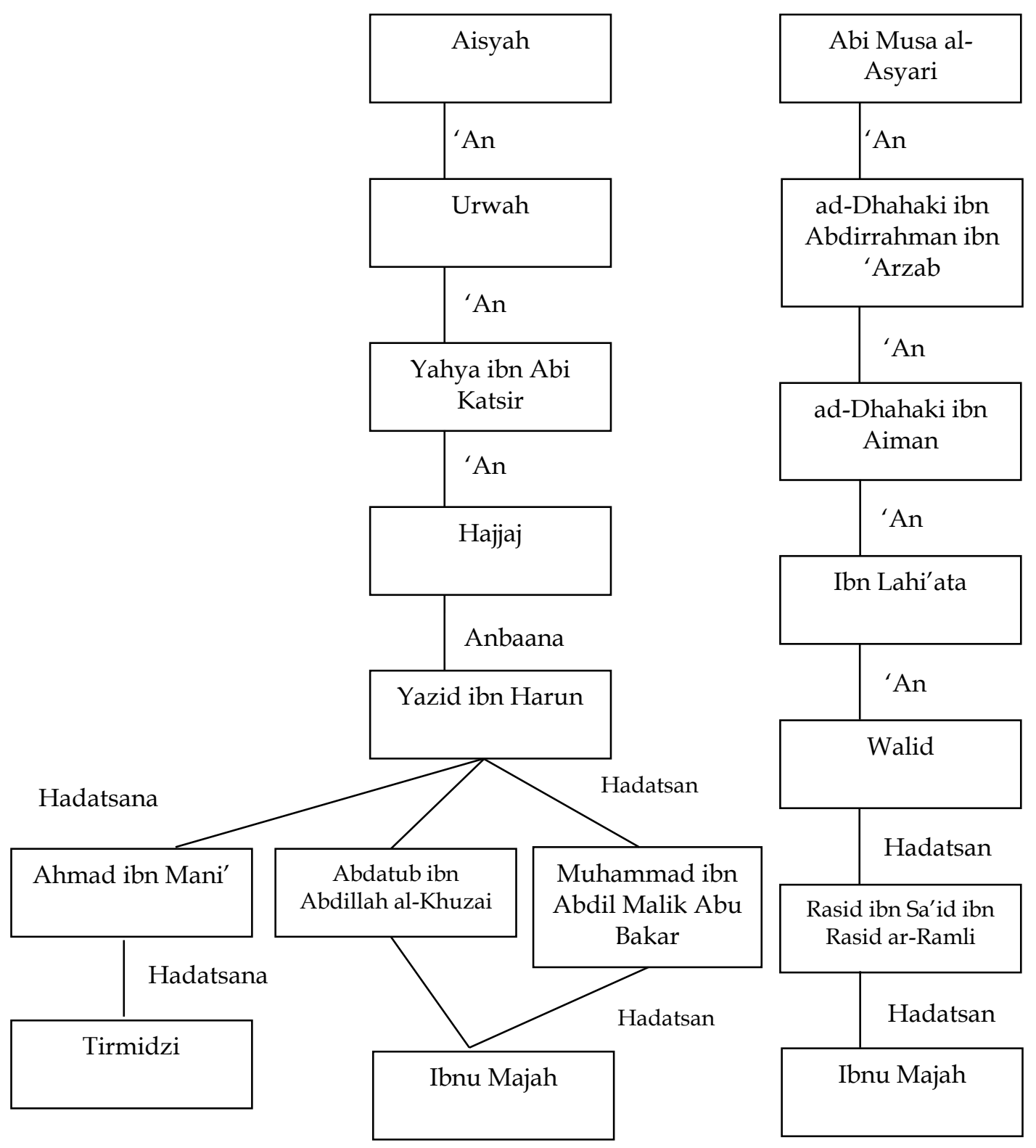



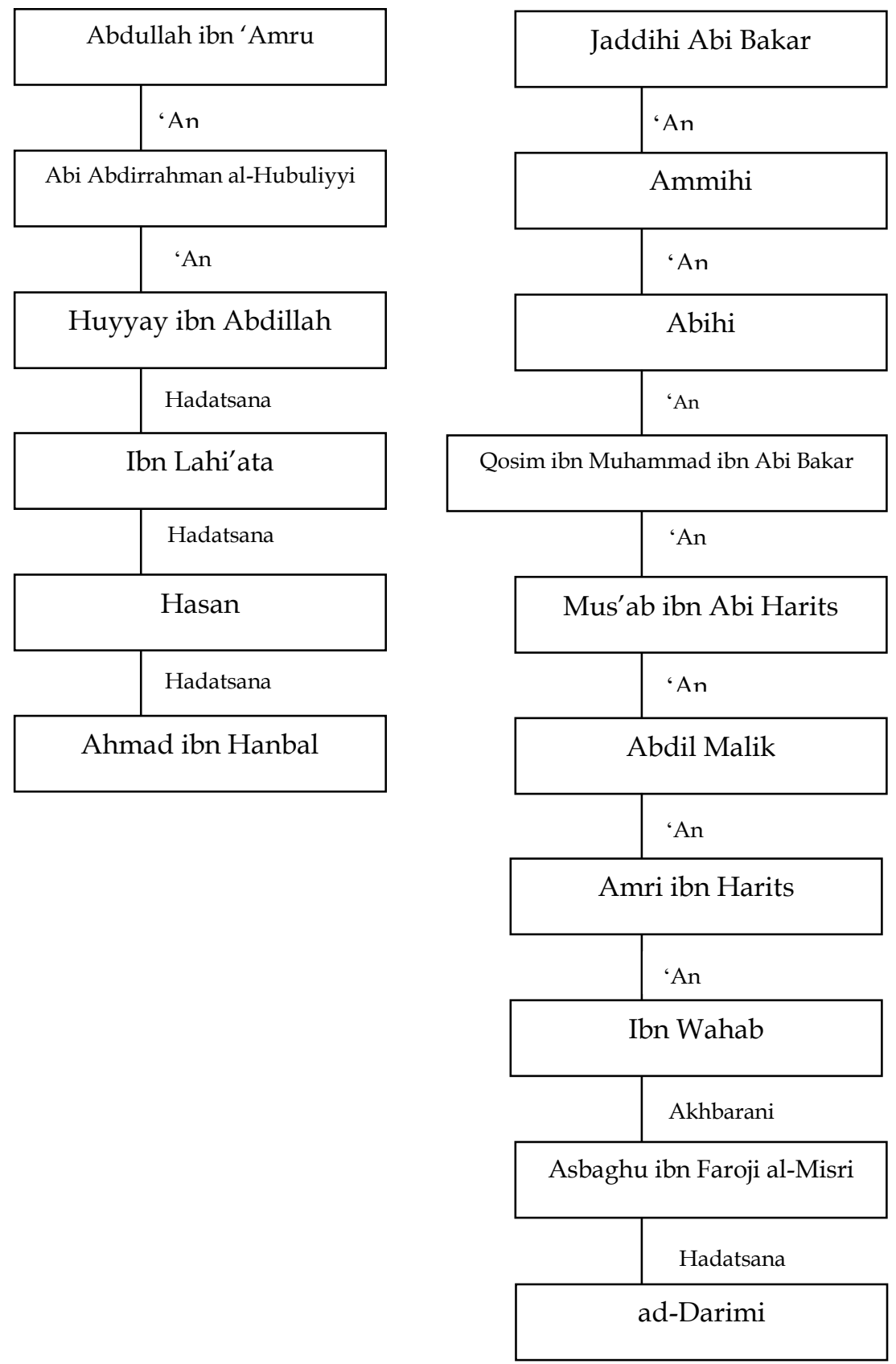
Pada jalur Rawi Aisyah terdapat nama perawi yang kedudukan perawinya dhoif yaitu Hajjaj, berdasarkan penelusuran peneliti pada aplikasi Islamweb.net disebutkan bahwa Hajjaj adalah orang yang tidak kuat, banyak kesalahan dan tadlis serta marratan dhoif. Dan jalur ini dimukhharijul oleh dua perawi yaitu jalur Ibnu Majah dan at-Tirmidzi. Oleh karena itu hadis pada jalur ini tidak dapat menjadi penguat hadis Ibnu Majah yang diriwayatkan oleh Ali ibn Abi Thalib.

Pada jalur rawi Abi Musa al-Asyari terdapat nama perawi yang tidak kenal, dan Ibn Hajar asQolani menyebutkan di dalam aplikasi web Islamweb.net bahwa ad-Dhahaki ibn Aiman ini orang yang majbul. oleh karena itu, hadis pada jalur ini tidak bisa dijadikan penguat atau pendamping hadis ibnu Majah yang diriwayatkan oleh Ali ibn Abi Thalib.

Pada jalur rawi Abi Bakar, terdapat nama perawi yang dinilai sebagai munkirul hadis jiddan, serta seseorang yang tidak diketahui. Ini disampaikan oleh kritikus hadis seperti Abu Bakar alBazzar dan Abu Hatim ibn Hibban di dalam aplikasi web Islamweb.net. Oleh karena itu hadis ini tidak bisa menjadi penguat bagi jalur hadis yang diriwayatkan oleh Ali ibn Abi Thalib.

Pada jalur rawi Abdullah ibn 'Amru terdapat nama perawi yang dikategorikan seorang dhoif berdasarkan penilaian kritikus hadis di dalam aplikasi web Islamweb.net, perawi tersebut ialah Ibn Lahi'ata yang dikritik oleh Abu Hatim Ar-Razi sebagai seorang yang dhoif. Oleh karena itu jalur sanad ini tidak bisa dijadikan penguat bagi jalur sanad dari rawi Ali Ibn Abi Thalib.

Setelah melakukan i'tibar jalur sanad di atas, peneliti selanjutnya menguraikan beberapa perawi hadis yang diriwayatkan oleh Ibnu Majah di atas adalah sebagai berikut: Ibnu Majah, Hasan bin Ali al-Khallal, Abd. Ar-Razzaq, Ibnu Abi Sabrah, Ibrahim bin Muhammad, Mu'awiyah bin Abdullah bin Ja'far, Abu Mu'awiyah, dan Ali bin Abi Thalib. Adapun biografi masing-masing perawi, analisis kebersambungan sanad, kualitas pribadi dan kapasitas intelektual perawi, serta terbebasnya sanad tersebut dari syadz dan 'illat akan diuraikan berikut ini:

\section{Kualitas Pribadi dan Kapasitas Intelektual Perawi}

\section{a. Ibnu Majah}


Ibnu Majah memiliki nama lengkap Muhammad ibn Yazíd al-Raba’iy. Beliau yang juga dikenal dengan nama Abu Abdullah ibn Majah al-Qazwíní ini memiliki kitab Sunan dan sering melakukan perjalanan jauh. Namanya dikenal di Khurasan, Irak, Hijaz, Mesir, Syam dan beberapa negara lainnya ${ }^{4}$ Riwayat lain menyatakan bahwa Ibnu Majah pernah melakukan perjalanan ke Urak, Basrah, Kufah, Baghdad, Mekkah, Syam dan Mesir. ${ }^{5}$ Ibnu Majah dilahirkan pada tahun $209 \mathrm{H}$ dan wafat pada hari Senin kemudian dimakamkan pada hari Selasa tepat delapan hari terakhir bulan Ramadhan tahun 273 H. Berdasarkan keterangan al-Mizzi, Ibnu Majah mencapai usia 64 tahun. ${ }^{6}$

Al-Mizzi tidak memberikan keterangan tentang jumlah guru Ibnu Majah serta siapa saja gurunya. Keterangan lebih lengkap tentang jumlah guru Ibnu Majah, peneliti temukan dalam CD Maktabah al-A'lam wa al-Tarajim. Jumlah guru Ibnu Majah 23 orang, di antaranya adalah 'Ali ibn Muhammad alThanáfasí, Mush'ab ibn Abdillah al-Zubairí dan Abu Bakar ibn Abí Syaibah.' Sedangkan jumlah murid Ibnu Majah menurut al-Mizzi adalah 11 orang, di antaranya adalah Ibrahim ibn Dinar al-Hausyabí al-Hamadzání, Ja’far ibn Idrís dan Muhammad ibn 'Isá al-Shaffár. ${ }^{8}$

Ibnu Majah meriwayatkan hadis dari Hasan ibn 'Alí al-Khallál dengan sighat haddatsaná. Sighat tersebut-meskipun tidak terdapat keseragaman pandangan ulama apakah digunakan untuk metode al-sima', al-gira'ah atau alijazah- menunjukkan adanya kebersambungan sanad antara ibn Majah dan Hasan ibn 'Alí al-Khallál. Kesimpulan tersebut memberi keyakinan saat peneliti mencermati rentang waktu hidup Hasan ibn 'Alí al-Khallál (179-242 H) dan ibn Majah (209-273 H). Meskipun Hasan ibn 'Alí al-Khallál tidak tercatat di dalam daftar nama guru Ibnu Majah, akan tetapi Ibnu Majah termasuk ke dalam Jama'ah yang tercatat di dalam daftar murid Hasan ibn 'Alí al-Khallál. Dengan demikian, berarti ada kebersambungan sanad di antara keduanya.

Penilaian kritikus hadis terhadap Ibnu Majah disampaikan oleh alDzahabi, Ibn Hajar, al-Nasa'i, al-Khatib dan Abu Ya'la al-Khalil al-Qazwiní. Al-Dzahabi menyatakan bahwa Ibnu Majah adalah orang yang Tsiqah. Ibn Hajar dalam kitab al-Tadzhib dan al-Nasa’i mengatakan Tsiqah. Begitu pula al-

\footnotetext{
${ }^{4}$ Jamal al-Din Abi al-Hujjaj Yusuf al-Mizzi, Tahdzib al-Kamal fi Asma' al-Rijal, Jilid 27, (Beirut: Muassasah al-Risalah, 1992), 40

${ }^{5}$ al-Mizzi, Tahdrib al-Kamal.... 41

${ }^{6}$ al-Mizzi, Tabdzib al-Kamal.... 41

${ }^{7}$ CD Maktabah al-A'lām wa Al-Tarājim

8 al-Mizzi, Tahdzib al-Kamal... 40-41
} 
Khatib menyatakan bahwa Ibnu Majah dengan 'Ábidan dan dalam al-Taqríb mengatakan Tsiqatun ábidun.' Selain itu, Abu Ya'la al-Khalil al-Qazwiní menyatakan bahwa Ibnu Majah adalah seorang yang tsiqatun kabirun, muttafaqun 'alaibi, mubtajjun bibi. ${ }^{10}$

\section{b. Hasan bin Ali al-Khallal}

Nama lengkapnya adalah Al-Hasan ibn 'Ali ibn Muhammad al-Hudzallí al-Khallál. ${ }^{11}$ Beliau juga dikenal dengan gelar Abu 'Alí, Abu Muhammad, alHulwání al-Raiháni. ${ }^{12}$ Beliau wafat di Mekkah pada tahun $242 \mathrm{H} .{ }^{13}$ Berdasarkan keterangan tahun wafatnya, maka dapat disimpulkan bahwa usia Hasan ibn 'Alí al-Khallál disamakan dengan umur Nabi Muhammad SAW 63 tahun, maka tahun kelahiran beliau menjadi atau sekitar tahun $179 \mathrm{H}$.

Terdapat kurang lebih 58 orang guru yang meriwayatkan hadis kepadanya. Di antaranya adalah Zayd ibn al-Hubbáb, Sulaimán ibn Harb dan 'Abd al-Razzáq ibn Hammám. ${ }^{14}$ Sedangkan murid dan orang yang meriwayatkan hadis darinya tidak kurang dari 17 orang di antaranya adalah Jamá'ah selain Nasa'i, Ibrahim ibn Isháq al-Harbíy dan Ahmad ibn 'Alí alAbbár. ${ }^{15}$ Hasan ibn 'Alí al-Khallál meriwayatkan hadis dari 'Abd al-Razzáq dengan sighat haddatsana. Dengan tercatatnya nama 'Abd al-Razzáq sebagai guru Hasan ibn 'Alí al-Khallál dan sebaliknya Hasan ibn 'Alí al-Khallál tercatat sebagai murid dari 'Abd al-Razzáq, maka antara Hasan ibn 'Alí al-Khallál dan 'Abd al-Razzáq terjadi pertalian langsung dalam proses transformasi hadis tersebut.

Penilaian kritikus hadis kepada Hasan bin Ali al-Khallal disampaikan oleh Ya'qub ibn Syaibah, Abu Daud, Al-Nasa'I, Abu Bakar al-Khatíb, dan Ibrahim ibn Aurumah al-Hafidz. Ya'qub ibn Syaibah menyatakan bahwa Hasan bin Ali al-Khallal adalah Tsiqah Tsabit Mutqinan, Abu Daud menyatakan orang yang 'Alim, Al-Nasa'i mengatakan Tsiqah, Abu Bakar al-Khatíb berpendapat Tsiqatan Háfidhan. ${ }^{16}$ Berdasarkan penilaian kritikus tersebut, maka Hasan bin Ali

\footnotetext{
${ }^{9}$ al-Mizzi, Tabdzib al-Kamal.... , 40

${ }^{10}$ al-Mizzi, Tabdzib al-Kamal.... 41

${ }^{11}$ Jamal al-Din Abi al-Hujjaj Yusuf al-Mizzi, Tahdrib al-Kamal fi Asma' al-Rijal, Jilid 6, (Beirut: Muassasah al-Risalah, 1992), 259

12 al-Mizzi, Tahdzib al-Kamal.... 260

13 al-Mizzi, Tahdrib al-Kamal.... 263

${ }^{14}$ Jamal al-Din Abi al-Hujjaj Yusuf al-Mizzi, Tabdrib al-Kamal fi Asma' al-Rijal, Jilid 18, (Beirut:

Muassasah al-Risalah, 1992), 260-261

15 al-Mizzi, Tahdzib al-Kamal.... 261-262

16al-Mizzi, Tahdrib al-Kamal.... Jilid 6, 262-263
} 
al-Khallal dapat dikategorikan sebagai perawi berpredikat maqbul karena masuk ke dalam tingkatan ta'dil kedua.

\section{c. Abd.Ar-Razzaq}

Abd. Ar-Razzaq bernama 'Abd al-Razzáq ibn Hammám ibn Náfi' alHimyariy al-Yamániy. Beliau juga dikenal dengan gelar Abu Bakar alShun'ániy. ${ }^{17}$ Menurut Muhammad ibn Abbán al-Balkhíy, sejak berusia antara 7 dan 8 tahun, 'Abd al-Razzáq telah mengikuti majelis ma'mar. ${ }^{18}$ Menurut Ahmad ibn Hanbal, 'Abd al-Razzáq dilahirkan pada tahun $126 \mathrm{H}^{19}$ ' Sedangkan menurut Muhammad ibn Sa'ad, Khalífah ibn Khayyát dan al-Bukhárí, beliau wafat pada tahun $211 \mathrm{H}^{20}$ Keterangan mengenai bulan wafatnya disampaikan oleh Muhammad ibn Sa'ad yaitu pada pertengahan bulan Syawal. ${ }^{21}$ Berdasarkan keterangan tentang tahun kelahiran dan wafatnya 'Abd al-Razzáq tersebut, maka peneliti menyimpulkan bahwa beliau mencapai usia 85 tahun.

Jumlah guru yang meriwayatkan hadis kepada 'Abd al-Razzáq tidak kurang dari 67 orang, yang di antaranya adalah Hisyám ibn Hasán, Ja'far ibn Sulaimán al-Dhuba'í dan Abu Bakar ibn 'Abdillah ibn Abi Sabrah. ${ }^{22}$ Sedangkan jumlah murid dan orang yang meriwayatkan hadis darinya berjumlah tidak kurang dari 84 orang. Di antaranya adalah Al-Hasán ibn 'Ali al-Khallál, Muhammad ibn Dáud ibn Sufyán dan Yahya ibn Músá. ${ }^{23}$

'Abd al-Razzáq meriwayatkan hadis dari Ibn Abí Sabrah dengan sighat anbaaná. Para ulama hadis sepakat bahwa sighat tersebut dipakai dalam periwayatan dengan jalur al-qiráah dan mereka tidak sepakat dalam pemakaian sighat tersebt untuk periwayatan dengan jalur al-ijąah. Antara dua perawi tersebut terdapat bentuk relasi murid dan guru. Artinya, tercatatnya nama 'Abd al-Razzáq dalam jajaran murid Ibn Abí Sabrah dan nama Ibn Abí Sabrah dalam jajaran guru 'Abd al-Razzáq, cukup menjadi bukti bahwa ada kebersambungan sanad antara keduanya.

Beberapa ahli kritik hadis memberikan penilaian kepada Abd. ArRazzaq seperti: Abbas al-Dauri, Abu Zur'atu ad-Dimasyqi, Abu Bakar ibn Abi Khaitsamah, dan Ya'kúb ibn Syaibah. Abbas al-Dauri berpendapat bahwa 'Abd

\footnotetext{
17 al-Mizzi, Tahdzib al-Kamal.... 52

18 al-Mizzi, Tabdzib al-Kamal.... 56

${ }^{19}$ Ahmad ibn Hanbal dalam al-Mizzi, Tabdrib al-Kamal.... 61

${ }^{20}$ Muhammad ibn Sa'ad, Khalífah ibn Khayyát dan al-Bukhárí dalam al-Mizzi, Tahdzৃib alKamal.... 61

${ }^{21}$ Muhammad ibn Sa'ad dalam al-Mizzi, Tahdzৃib al-Kamal.... 61

22 al-Mizzi, Tahdzib al-Kamal.... 52-54

23 al-Mizzi, Tabdzib al-Kamal.... 54-56
} 
al-Razzáq adalah seorang yang tsabit dalam hadis Ma'mar dari Hisyam ibn Yusuf.Abu Zur'atu ad-Dimasyqi bertanya siapa yang paling tsabit diantara Ibnu Juraih, 'Abd al-Razzáq dan Bursani? Ahmad menjawab 'Abd al-Razzáq.Abu Bakar ibn Abi Khaitsamah menyatakan bahwa 'Abd al-Razzáq adalah salah seorang ashbáb al-Tsauri, dan Ya'kúb ibn Syaibah menilai bahwa 'Abd al-Razzáq adalahTsiqatun Tsabtun. ${ }^{24}$

Berdasarkan penilaian para kritikus hadis, maka 'Abd al-Razzáq dapat dikelompokkan pada tinggkatan perawi yang ta'dil pertama sampai ketiga. Sehingga periwayatannya dapat dijadikan hujjah dan diterima.

\section{d. Ibnu Abi Sabrah}

Nama beliau adalah Abu Bakar ibn Abdillah ibn Muhammad ibn Abi Sabrah ibn Abi Ruhmi ibn 'Abd al-'Úzzá ibn Abi Qois ibn "Abdu Waddin ibn Nasr ibn Malik ibn Hisl ibn 'Amir ibn lu'yi ibn Ghalib al-Qurasyi al-'Amiriy alSabriy al-Madaniy. ${ }^{25}$ Menurut riwayat, namanya adalah 'Abdullah. Sedangkan menurut Ahmad ibn Hanbal dan Abu Hátim al-Rází, namanya adalah Muhammad. ${ }^{26}$ Riwayat lainnya menjelaskan bahwa beliau adalah saudara Muhammad ibn 'Abdillah ibn Abí Sabrah yang telah sampai di Madinah sebelum Ziyád ibn 'Ubaidillah al-Háritsí. Nasabnya sampai pada kakeknya Abi Sabrah yang bernama 'Abdullah yang merupakan salah seorang shahabat yang berperan serta dalam perang Badar. ${ }^{27}$ Ibn Abí Sabrah mengatakan bahwa dirinya menghafal 70 ribu hadis tentang halal dan haram. Diperkirakan Abí Sabrah lahir pada tahun pada tahun $102 \mathrm{H}$ karena menurut Muhammad ibn Sa'ad, beliau wafat pada tahun $162 \mathrm{H}$ dan usia beliau mencapai 60 tahun. ${ }^{28}$

Jumlah guru yang meriwayatkan hadis kepada Ibn Abí Sabrah sebanyak 21 orang, di antaranya adalah Ibrahim ibn Muhammad, Zayd ibn Aslam dan 'Isá ibn Ma'mar. ${ }^{29}$ Sedangkan jumlah murid yang meriwayatkan hadis darinya adalah 11 orang, di antaranya adalah Sulaiman ibn Muhammad ibn Abí Sabrah, 'Abd al-Razzáq ibn Hammám dan'Isá ibn Yúnus. ${ }^{30}$

\footnotetext{
${ }^{24}$ Al-Hafidz Abi Fadhil Ahmad bin Ali bin Hajar Syihab ad-Din al-'Asqalaani asy-Syafi'i, Tahzib at-Tahzhib, Juz 2 (Bairut: Muassah ar-Risalah, 1996), 572-574

${ }^{25}$ Jamal al-Din Abi al-Hujjaj Yusuf al-Mizzi, Tahdzib al-Kamal fi Asma' al-Rijal, Jilid 33, (Beirut: Muassasah al-Risalah, 1992), 102-103

${ }^{26}$ al-Mizzi, Tabdzib al-Kamal.... 103

27 al-Mizzi, Tabdzib al-Kamal.... 103

28 al-Mizzi, Tabdzib al-Kamal.... 106

${ }^{29}$ al-Mizzi, Tahdrib al-Kamal.... 103-104

30 al-Mizzi, Tabdzib al-Kamal.... 104
} 
Ibn Abí Sabrah meriwayatkan hadis dari Ibrahim ibn Muhammad secara secara mu'an'an (di antarai dengan lafadz 'an). Tidak adanya penyembunyian cacat (tadlis) antara dua perawi tersebut dapat dibuktikan dengan bentuk relasi murid dan guru. Artinya, tercatatnya nama Ibn Abí Sabrah dalam jajaran murid Ibrahim ibn Muhammad dan nama Ibrahim ibn Muhammad dalam jajaran guru Ibn Abí Sabrah, telah menjadi bukti bahwa ada kebersambungan sanad antara keduanya.

Para ahli kritik hadis memberikan penilaian negatif kepada Ibnu Abi Sabrah mereka adalah 'Ali ibn al-Madíníy mengatakan Ibnu Abi Sabrah adalah Dhoifan fi al-Hadits, Abdullah ibn Ahmad ibn Hanbal berkata dari Ahmad ibn Hanbalbahwa Ibnu Abi Sabrah adalah Yadhi'u al-Hadis wa Yakdribu, AlGhalábiy dari Yahyá ibn Ma'ín berpandangan bahwa Ibnu Abi Sabrah adalah Dho'if al-Hadits, Ibn Abi Yahya berpendapat Ibnu Abi Sabrah adalahMunkar alHadis, Ibrahim ibn Ya'kúb al-Júzajáníy memberikan penilaian Ibnu Abi Sabrah sebagai Yudha'af al-Hadis, Bukhori menilai perawi ini adalah Dhoif dan Munkar al-Hadis, Nasa'i menambahkan ia seorang perawi yang matrúk al-Hadis. ${ }^{31}$

Berdasarkan penilaian tersebut, maka perawi Ibnu Abi Sabrah masuk dalam kategori sanad yang dhoif, munkar, matruk dan dilihat dari urutan maratib jarh perawi tidak dapat dijadikan hujjah, tidak boleh ditulis hadisnya dan tidak dijadikan i’tibar.

\section{e. Ibrahim bin Muhammad}

Ibrabim ibn Muhammad. ${ }^{32}$ Tidak ada keterangan tentang tahun lahir dan wafat serta umur beliau dalam kitab Tabdrib al-Kamal fi Asma' al-Rijal karya alMazzí. Menurut al-Mazzí beliau hanya meriwayatkan hadis dari 1 orang guru yang bernama Mu'awiyah ibn Abdillah ibn Ja'far ${ }^{33}$ dan juga hanya memiliki 1 orang murid bernama Abu Bakar ibn Abi Sabroh. ${ }^{34}$

Ibrahim ibn Muhammad meriwayatkan hadis dari Mu'awiyah ibn 'Abdillah ibn Ja'far dengan sighat 'an (secara mu'an'an). Dengan disebutnya Mu'awiyah ibn 'Abdillah ibn Ja'far sebagai guru Ibrahim ibn Muhammad dan Ibrahim ibn Muhammad sebagai murid Mu'awiyah ibn 'Abdillah ibn Ja'far, maka antara keduanya terjadi pertautan langsung sehingga terdapat kebersambungan sanad.

\footnotetext{
${ }^{31}$ asy-Syafi'i, Tabzib at-Tahz̧bib, Juz 2,489-490

32 Jamal al-Din Abi al-Hujjaj Yusuf al-Mizzi, Tabdrib al-Kamal fi Asma' al-Rijal, Jilid 2, (Beirut:

Muassasah al-Risalah, 1992), 193

33 al-Mizzi, Tabdzib al-Kamal.... 193

34 al-Mizzi, Tabdziib al-Kamal.... 194
} 
Penilaian Ibrahim bin Muhammad diberikan oleh Ibnu Abi Hatim dan Ibnu Hibban. Ibnu Abi Hatim berpandangan bahwa Ibrahim bin Muhammad adalah shobibu tarjamah, sedangkan Ibnu Hibban menyebutnya sebagai perawi yang tsiqaat. ${ }^{35}$

Berdasarkan penilaian tersebut, maka Ibrahim bin Muhammad dapat dikategorikan sebagai perawi yang 'adil dan hadis yang diriwayatkannya bisa dijadikan hujjah.

\section{f. Mu'awiyah bin Abdullah bin Ja'far}

Nama lengkap Mu'awiyah ibn Abdillah ibn Ja'far ibn Abi Thalib alQurasiy al-Hasyimi al-Madani. ${ }^{36} \mathrm{Al}-\mathrm{Mizzi}$ tidak memberikan keterangan tentang tahun kelahiran dan wafatnya beliau, sehingga peneliti juga tidak dapat menyimpulkan tepatnya usia beliau.

Mu'awiyah ibn Abdillah ibn Ja'far adalah seorang mubaddits yang memiliki guru 5 orang dan murid 11 orang. Di antara sederet gurunya terdapat Ráfi' ibn Khadíj, Sáib ibn Yazíd dan Abu Mu'awiyah (Abdullah ibn Ja'far). ${ }^{37}$ Sedangkan di antara jajaran muridnya terdapat Ibrahim ibn Muhammad, Yazíd ibn 'Abdillah ibn al-Hád dan Muhammad ibn Muslim ibn Syiháb alZuhríyyu. ${ }^{38}$

Mu'awiyah ibn Abdillah ibn Ja'far meriwayatkan hadis dari ayahnya dengan sighat 'an (mu'an'an). Dengan adanya pertalian hubungan keluarga antara ayah dan anak serta disebutnya Abu Mu'áwiyah sebagai guru Mu'awiyah ibn Abdillah ibn Ja'far dan Mu'awiyah ibn Abdillah ibn Ja'far sebagai murid Abu Mu'áwiyah, maka antara keduanya terjadi pertautan langsung sehingga terdapat kebersambungan sanad.

Mu'awiyah bin Abdullah bin Ja'far mendapat penilaian dari kritikus hadis seperti 'Ijliyyu dan Ibnu Hibban. 'Ijliyyu mengatakan bahwa Mu'awiyah bin Abdullah bin Ja'far adalah Tsigoh, sedangkan Ibnu Hibban menilai perawi al-Tsiqat. ${ }^{39}$ Berdasarkan penilaian tersebut, maka Ibrahim bin Muhammad dapat dikategorikan sebagai perawi yang 'adil dan hadis yang diriwayatkannya bisa dijadikan hujjah.

\footnotetext{
${ }^{35} \mathrm{Al}-\mathrm{Hafidz}$ Abi Fadhil Ahmad bin Ali bin Hajar Syihab ad-Din al-'Asqalaani asy-Syafi'i, Tahzib at-Tahzhib, Juz. 1 (Bairut: Muassah ar-Risalah, 1996), 85

${ }^{36}$ Jamal al-Din Abi al-Hujjaj Yusuf al-Mizzi, Tabdrib al-Kamal fi Asma' al-Rijal, Jilid 28, (Beirut: Muassasah al-Risalah, 1992), 196

${ }^{37}$ al-Mizzi, Tabdzib al-Kamal.... 196

38 al-Mizzi, Tabdzib al-Kamal.... 197

${ }^{39}$ Al-Hafidz Abi Fadhil Ahmad bin Ali bin Hajar Syihab ad-Din al-'Asqalaani asy-Syafi'i, Tabzib at-Tahz̧ib, Juz 4 (Bairut: Muassah ar-Risalah, 1996), 110
} 


\section{g. Abu Mu'awiyah}

Nama lengkap Abdullah ibn Ja'far ibn Abi Thalib al-Qurasyiu alHasyimi. Beliau juga dikenal dengan gelar Abu Ja'far al-Madaníy, al-Jawwád ibn al-Jawwád. Ibunya adalah Asmá bintu 'Umays al-Khats'amiyyah. ${ }^{40}$ Beliau dilahirkan di Habsyah dan merupakan bayi pertama yang lahir di Habsyah dalam keadaan Islam. Diriwayatkan bahwa ketika Ja'far ibn Abí Thalib hijrah ke Habsyah, ia bersama istrinya yang sedang hamil bernama Asmá' bintu 'Umays, kemudian lahirlah putranya yang bernama Abdullah ibn Ja'far ibn Abi Thalib. ${ }^{41}$ Beliau merupakan seseorang yang baik hati dan lembut sehingga mendapat julukan Bahr al-Júd (lautan kebaikan). ${ }^{42}$ Al-Mizzi tidak memberikan keterangan tentang tahun kelahiran beliau, akan tetapi menulis berbagai pendapat tentang tahun wafat dan usia beliau. Menurut Zubayr ibn Bakkár, Abdullah ibn Ja'far ibn Abi Thalib wafat pada tahun $80 \mathrm{H}$ dan usianya mencapai 90 tahun. Saat itu wali Madinah adalah Abbán ibn 'Usmán ibn 'Affán di bawah kekuasaan Khalifah 'Abd al-Malik ibn Marwán. ${ }^{43}$ Pendapat lain menyatakan bahwa Abdullah ibn Ja'far ibn Abi Thalib wafat pada tahun $80 \mathrm{H}$ dan usianya mencapai 80 tahun. Pendapat terakhir menyatakan bahwa Abdullah ibn Ja'far ibn Abi Thalib wafat pada tahun $90 \mathrm{H}$ dalam usia 80 tahun. Kemudian al-Mizzi menyatakan bahwa pendapat yang menyatakan Abdullah ibn Ja'far ibn Abi Thalib wafat pada tahun $80 \mathrm{H}$ dengan usia 80 tahun adalah pendapat yang paling kuat. ${ }^{44}$

Al-Mizzi dalam kitabnya "Tahdrib al-Kamal fi Asma' al-Rijal" menyebutkan bahwa terdapat 5 orang guru yang meriwayatkan hadis kepada Abdullah ibn Ja'far ibn Abi Thalib, di antaranya adalah Rasulullah SAW, 'Usmán ibn 'Affán dan Ali ibn Abi Thalib. ${ }^{45}$ Selain itu, al-Mizzi juga menyebutkan bahwa terdapat 27 orang murid yang meriwayatkan hadis darinya. Di antara murid-murid beliau adalah 'Urwah ibn al-Zubair, Muhammad ibn 'Abdillah dan anaknya yang bernama Mu'awiyah ibn 'Abdillah ibn Ja'far. ${ }^{46}$

\footnotetext{
40 Jamal al-Din Abi al-Hujjaj Yusuf al-Mizzi, Tabdrib al-Kamal fi Asma' al-Rijal, Jilid 14, (Beirut: Muassasah al-Risalah, 1992), 367

${ }^{41}$ al-Mizzi, Tahdzib al-Kamal.... 368-369

42 al-Mizzi, Tabdrib al-Kamal... 367

43 Zubayr ibn Bakkár dalam al-Mizzi, Tabdæib al-Kamal... 372

44 al-Mizzi, Tahdzib al-Kamal... 372

45 al-Mizzi, Tahdzib al-Kamal... 367

46 al-Mizzi, Tabdrib al-Kamal.... 368
} 
Abu Mu'awiyah meriwayatkan hadis dari 'Ali ibn Abi Thalib dengan sighat 'an (mu'an'an). Tidak adanya penyembunyian cacat (tadlis) antara dua perawi tersebut dapat dibuktikan dengan bentuk relasi murid dan guru. Artinya, tercatatnya nama Abu Mu'awiyah dalam jajaran murid 'Ali ibn Abi Thalib dan nama 'Ali ibn Abi Thalib dalam jajaran guru Abu Mu'awiyah, serta adanya hubungan keluarga antara keduanya sebagai seorang paman dan keponakannya, cukup menjadi bukti bahwa ada kebersambungan sanad antara keduanya.

Penilaian dari beberapa ahli hadis tentang kualitas pribadi Abu Mu'awiyah disampaikan oleh Mu'awiyah dan Al-Zubair ibn Bakkár. Mu'awiyah mengatakan seorang laki-laki bani hasyim bernama Abdullah ibn Ja'far adalah orang yang terhormat/mulia, Al-Zubair ibn Bakkár menyatakan Abu Mu'awiyah adalah Jawwádan Mumaddahan.$^{47}$ Berdasarkan penilaian di atas, Abu Mu'awiyah dapat dikategorikan sebagai perawi yang 'adil dan maqbul karena tidak ditemukan jarh pada diri perawi.

\section{h. Ali bin Abi Tholib}

Nama lengkapnya adalah Ali ibn Abi Thalib 'Abdu Manaf ibn 'Abd alMuthallib ibn Hasyim al-Qurasyi. Beliau mendapat gelar Abu al-Hasan alHásyimíy, Amir al-Mukminín dan merupakan putra dari paman Rasulullah SAW. ${ }^{48}$ Beliau juga dikenal dengan julukan Aba Turáb dan banyak hadis masyhur yang menyebutkan hal tersebut. ${ }^{49}$ Ibunya adalah Fatimah bintu Asad ibn Hásyim al-Hásyimiyyah yang merupakan putri pertama dari Bani Hasyim dan wafat pada masa Rasulullah SAW. "Ali ibn Abi Thalib adalah seorang sahabat yang berperan serta dalam perang Badar dan semua perang yang diikuti Rasulullah SAW bahkan perang Tabuk. ${ }^{51}$

Beberapa ulama berpendapat bahwa 'Ali ibn Abi Thálib adalah putra bungsu Abí Thalib. Ia 10 tahun lebih muda dari Ja'far, Ja'far 10 tahun lebih muda dari 'Aqíl dan 'Aqíl 10 tahun lebih muda dari Thálib. ${ }^{52}$ Menurut ibn Isháq, 'Ali ibn Abí Thálib merupakan pemuda pertama yang memeluk agama Islam setelah Khadijah. ${ }^{53}$ Al-Layts berpendapat bahwa 'Ali ibn Ab'i Thálib memeluk agama Islam saat berusia 8 tahun, sedangkan menurut ibn Isháq saat

\footnotetext{
${ }^{47}$ asy-Syafi'i, Tahz̨ib at-Tabzhib, Juz 2, 313

48 Jamal al-Din Abi al-Hujjaj Yusuf al-Mizzi, Tahdzib al-Kamal fi Asma' al-Rijal, Jilid 20, (Beirut: Muassasah al-Risalah, 1992), 472

${ }^{49}$ al-Mizzi, Tabdzib al-Kamal.... 473

50 al-Mizzi, Tabdzib al-Kamal.... 473

51 al-Mizzi, Tabdzib al-Kamal.... 473

52 al-Mizzi, Tabdzib al-Kamal.... 479

${ }^{53}$ al-Mizzi, Tabdzib al-Kamal.... 480
} 
beliau berusia 10 tahun. ${ }^{54}$ Selain itu, Ibn Umar berpendapat bahwa 'Ali ibn Ab'i Thálib memeluk agama Islam saat berusia 12 tahun. ${ }^{55}$

Terdapat beberapa perbedaan tentang tanggal wafatnya Ali bin Abi Tholib. Sebagian berpendapat bahwa beliau dibunuh pada malam Jum'at tanggal 13, sedangkan riwayat lain menyatakan bahwa beliau dibunuh pada tanggal 11 Ramadhan tahun $40 \mathrm{H}$. Terdapat banyak perbedaan pendapat tentang usia belian saat wafat. Sebagian menyatakan usianya 57 atau 58 tahun. Abu Nu'aim dan lainnya sepakat bahwa usia 'Ali ibn Abí Thálib mencapai 63 tahun. Abi Ja'far Muhammad ibn 'Ali ibn Husain menyatakan bahwa 'Ali ibn Abí Thálib terbunuh saat berusia 63 tahun. Sedangkan ibn Juraij dari Muhammad ibn 'Ali menyatakan bahwa 'Ali ibn Abí Thálib terbunuh saat berusia 63 atau 64 tahun. $^{56}$ Berdasarkan keterangan tersebut peneliti menyimpulkan bahwa 'Ali ibn Abí Thálib terbunuh saat berusia 63 tahun.

'Ali ibn Abí Thálib adalah seorang mubaddits yang memiliki 5 orang guru yang meriwayatkan hadis kepadanya. Di antaranya adalah Rasulullah SAW, Abu Bakar dan Miqdad ibn Aswad. ${ }^{57}$ Sedangkan jumlah murid dan orang yang meriwayatkan hadis darinya berjumlah 260 orang, yang di antaranya adalah 'Ubbád ibn Abi Yazíd, Zayd ibn Arqam al-Ansháriy dan Abdullah ibn Ja'far ibn Abi Thalib. ${ }^{58}$

Berdasarkan berbagai keterangan tersebut, tidaklah keliru jika di dalam penelitian tentang pribadi 'Ali ibn Abí Thálib, peneliti berpegang pada kesepakatan jumhur ulama al-shahabah kulluhum 'udul. Dengan demikian, maka penelitian terhadap kredibilitas 'Ali ibn Abí Thálib tidak diperlukan lagi. Sementara pertautan 'Ali ibn Abí Thálib dengan Nabi tidak perlu diragukan. Dengan demikian, dapat diambil kesimpulan bahwa seluruh jajaran perawi dengan sanad hadis tersebut bersambung.

Ali bin Abi Tholib mendapatkan penilaian dari Ibnu Abdi al-Barr bahwa Ali ibn Abi Thalib adalah orang pertama kali masuk Islam, sedangkan Ahmad ibn Hanbal menilai bahwa sesungguhnya belum meriwayatkan seorang dari sahabat seperti apa yang diriwayatkannya Ali. ${ }^{59}$ Berdasarkan penilaian

\footnotetext{
54 al-Mizzi, Tahdzib al-Kamal.... 481

55 al-Mizzi, Tahdrib al-Kamal.... 482

56 al-Mizzi, Tabdrib al-Kamal... 488

57 al-Mizzi, Tabdrib al-Kamal... 473

58 al-Mizzi, Tabdzib al-Kamal.... 473-479

${ }^{59} \mathrm{Al}-\mathrm{Hafidz}$ Abi Fadhil Ahmad bin Ali bin Hajar Syihab ad-Din al-'Asqalaani asy-Syafi'i, Tahrib at-Tabzbib, Juz 3 (Bairut: Muassah ar-Risalah, 1996), 169-171
} 
tersebut, tidak didapatkan jarb pada seorang Ali bin Abi Tholib sehingga hadis yang diriwayatkannya bisa diterima.

\section{Meneliti Syadz dan Illat pada Sanad Hadis}

Berdasarkan i'tibar hadis yang peneliti lakukan sebelumnya terdapat beberapa jalur sanad hadis yang memiliki kemiripan secara matan dengan jalur sanad yang diriwayatkan oleh Ibnu Majah, yaitu jalur sanad dari Tirmidzi, Ahmad ibn Hanbal dan Darimi. Dan jalur periwayatan Ibnu Majah pun memiliki tiga jalur sanad yang matannya memiliki kemiripan. Di bawah ini akan peneliti uraikan jalur sanad dan melihat kualitas seluruh perawi tersebut.

Ketiga jalur Sanad Ibnu Majah ialah:

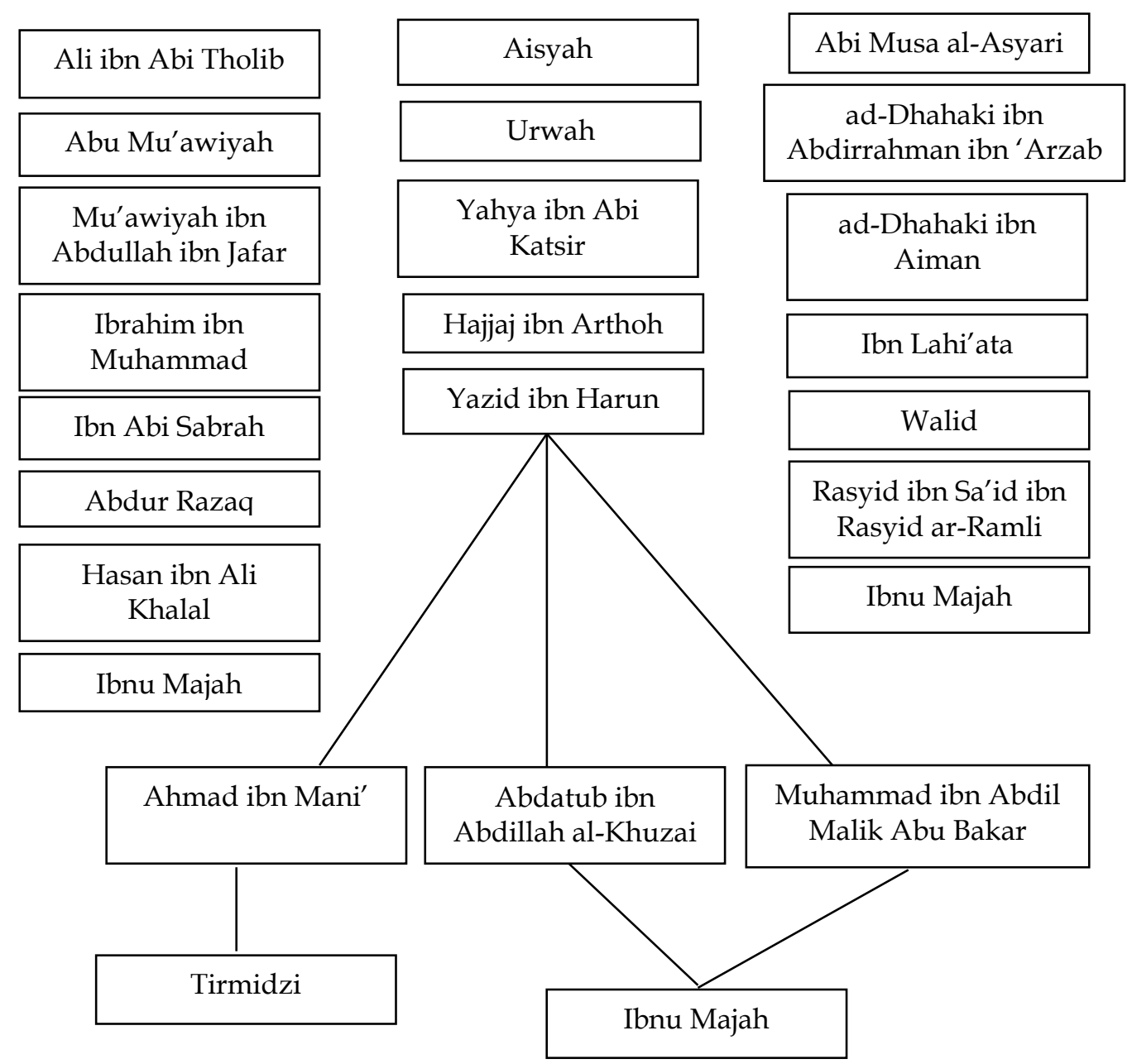


Bila pada jalur sanad Ibnu Majah yang peneliti jadikan landasan dalam tradisi malam nisyfu sya'ban ini itu terdapat perawi yang tidak bisa dijadikan hujjah dan i'tibar serta tidak bisa dicatat. Perawi tersebut adalah Ibnu Abi Sabrah yang berkualitas matruk, dhoif, yadho'u, yakdribu, munkar. Oleh karena itu, hadis yang sanadnya terdapat perawi pendusta termasuk dalam kategori hadis maudhu' yaitu hadis yang dibuat oleh seorang perawi (pendusta) yang disambungkan kepada Nabi secara palsu baik sengaja maupun tidak.

Bila dibandingkan dengan jalur sanad Ibnu Majah yang kedua dari rawi Aisyah, didapatkan beberapa perawi yang tsiqoh seperti Urwah, Yahya ibn Katsir, Yazid ibn Harun, Muhammad ibn Abddil Malik Abu Bakar dan 'Abdatub Ibn Abdillah al-Khuzai. Namun pada tingkatan ketujuh ada seorang perawi bernama Hajjjaj ibn ibn Arthoh yang memiliki kualitas dhoif sebagaimana penilaian para kritikus sanad hadis diantaranya ialah Ibn Hajar Asqolani yang memberi nilai dhoifun mudallasun. Jalur dari Aisyah ini pula dimukharij oleh Tirmidzi dengan jalur yang sama namun berbeda pada tingkatan kesembilan yaitu dari gurunya Ahmad ibn Mani' yang berkualitas tsiqoh.

Sedangkan bila dibandingkan dengan jalur sanad ibnu Majah yang ketiga dari rawi Abi Musa al-Asy'ari didapati beberapa rawi yang tsiqoh diantaranya ialah ad-Dhahaki ibn Abdirrahman ibn 'Arzab, Walid, Rasyid ibn Sa'id ibn Rasyid ar-Ramli. Sedangkan terdapat dua perawi pada jalur ini yang termasuk kategori dhoif serta majbul yaitu ad-Dhahaki ibn Aiman dan Ibn Lahi'ata. Bila disimpulkan dari ketiga jalur ibnu Majah ditambah jalur Tirmidzi ini semua memiliki perawi yang tingkat ketsiqobannya tidak kuat walaupun jalurnya bersambung dan mursal hingga Rasulullah seperti pada jalur Ibnu Majah yang pertama. 


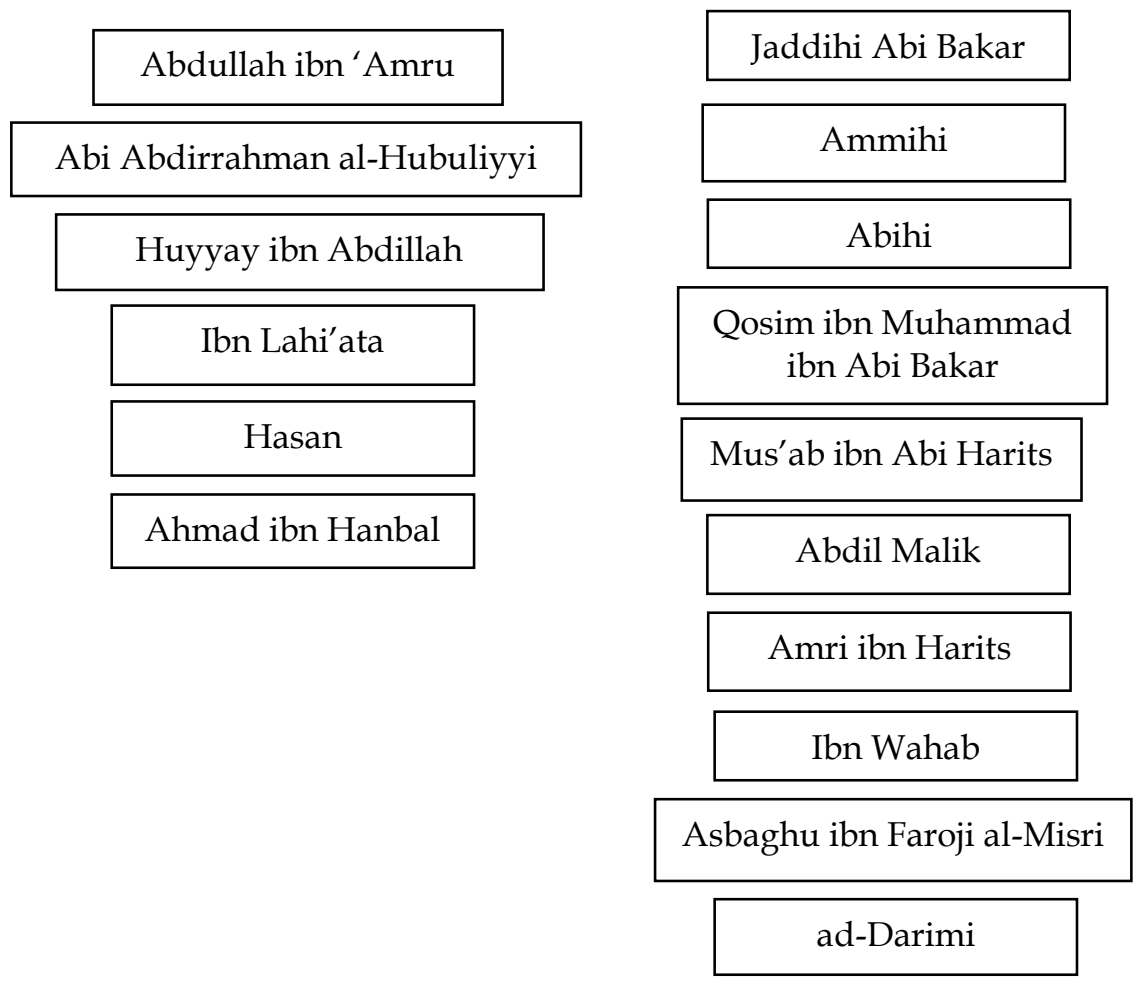

Sedangkan bila dibandingkan dengan jalur sanad Ahmad ibn Hanbal didapati bahwa perawi-perawi ini dikategorikan sebagai perawi tsiqoh, Abdullah ibn 'Amru, Abi Abdurrahman al-Hubuliyyi dan Hasan. Huyyay ibn Abdillah dinilai orang yang tidak tsiqoh karena itu periwayatannya munkar dan tidak kuat menurut kritikus hadis. Termasuk juga muridnya yang bernama ibn Lahi'ata yang dikategorikan sebagai dhoif hadis.

Sedangkan bila dibandingkan dengan jalur sanad dari ad-Darimi yang diriwayatkan pertama oleh Abi Bakar terdapat beberapa perawi tsiqob yaitu 'ammihi yaitu Abdurrahman ibn Abdullah, Abihi yaitu Muhammad ibn Abdullah, Qosim ibn Muhammad ibn Abi Bakar, 'Amri ibn Harits, Ibn Wahab, Asbaghun ibn Faroji al-Misri. Sedangkan dua perawi dinilai oleh kritikus hadis merupakan perawi yang tidak dikenal yaitu Mus'ab ibn Abi Harits dan Abdil Malik. Berdasarkan perbandingan jalur sanad tersebut disimpulkan bahwa setiap jalur sanad memiliki perawi yang dhoif baik itu satu sanad ataupun lebih hal ini menyalahi jalur sanad lain yang berkualitas tsiqoh dan ini menyebabkan hadis sanad yang meriwayatkan matan nisyfu sya'ban mengandung syadz. 


\section{Kajian Kritik Matan}

Penelitian terhadap matan hadis tentang malam nishfu' sya'ban ini tidak peneliti lakukan dikarenakan satu sanadnya berkualitas matruk, dhoif, yadho'u, yakdzibu, munkar, dan syeikh al-Albany lebih keras lagi memutuskan bahwa sanad hadis Ibnu Majah ini berkualitas palsu yang disandarkan kepada Ibnu Abi Sabrah. Walaupun demikian makna kandungan hadis tersebut perlu dikaji dan diteliti karena menurut peneliti tidak bertentangan dengan al-Qur'an maupun hadis lain yang lebih shahih. Akan tetapi hadis ini tidak bisa dijadikan sumber utama karena sanad hadisnya lemah.

Berdasarkan kitab syarah sunan Ibnu Majah, bahwa hadis yang berkenaan dengan malam nishfu Sya'ban ini sanadnya berkualitas lemah/dhoif, Ahmad bin Hanbal dan Ibnu Mu'in menambahkan bahwa sanadnya lemah karena Ibnu Abi Sabrah merupakan seorang pemalsu hadis. ${ }^{60}$

\section{Kajian Kandungan Hadis}

Pada aspek ini, peneliti menggunakan pendekatan yang ditawarkan oleh al-Ghazali yaitu dalam memahami kandungan matan hadis perlu empat langkah atau metode sehingga dapat memberikan makna kandungan yang sesuai dengan teks dan konteksnya. Di dalam hadis Ibnu Majah ada tiga poin dalam makna matan yaitu qiyamul lail di malam nisfbu Sya'ban, berpuasa di siang harinya dan berdoa di hari nishfu Sya'ban. Untuk menguji makna kandungan hadis tersebut perlu dilakukan empat langkah berikut:

a. Konfirmasi dengan ayat-ayat suci al-Qur'an;

Al-Ghazali di dalam kitabnya as-Sunnah an-Nabawiyah Baina Abli al-Fiqh wa Abli al-badis mengatakan :

Dengan metode ini, mereka meneladani para sahabat dan tabi'in, misalnya, sikap Aisyah r.a. ketika mendengar hadis yang menyatakan bahwa orang mati diazab karena tangisan keluarganya terhadapnya. Ia menolaknya dan menjelaskan alasan penolakannya dengan berkata: adakah kalian lupa akan firman Allah SWT, tidaklah seseorang menanggung dosa orang lain... (al-An'am : 164). Demikianlah, Aisyah dengan tegas dan berani telah menolak periwayatan suatu "hadis" yang bertentangan dengan al-Qur'an. ${ }^{61}$

\footnotetext{
${ }^{60}$ Roid Shobrah Abu 'Alfah, Syuruh Sunan Ibnu Majah, Juz I, (Aman: Baitul Afkar Ad-Dauliyah, 2007), 556-557

${ }^{61}$ Muhammad al-Ghazali, as-Sunnah an-Nabawiyah Baina Abli al-Fiqh wa Abli al-hadi,(Studi Kritis Hadis Nabi SAW., Antara Pemahaman Tekstual dan Kontekstual, Terj. Muhammad al-Baqir), (Bandung: Mizan, Cet. II, 1992), 29
} 
Makna kandungan hadis yang pertama ialah qiyamul lail, bila dikonfirmasi dengan ayat suci al-Qur'an, maka dapat ditemuakan beberapa ayat suci yang menerangkan akan nikmatnya ibadah sholat di tengah malam seperti di dalam surat al-Isra' ayat 78-79 berikut ini:

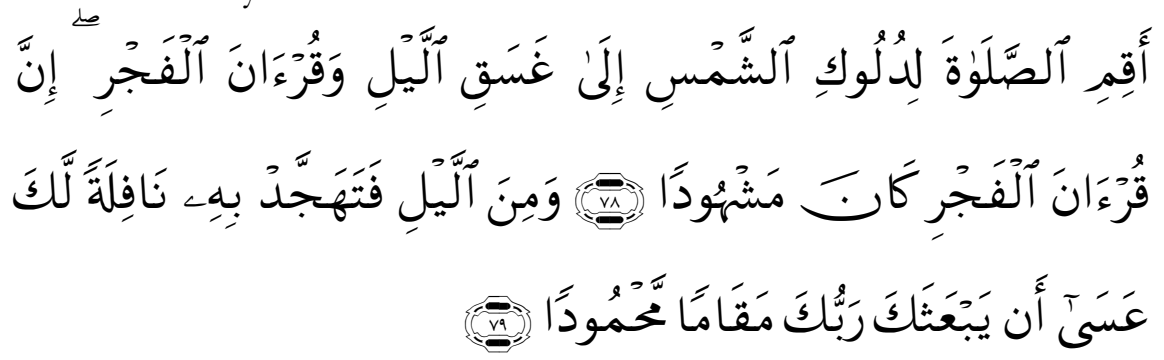

Artinya: "dirikanlah shalat dari sesudah matahari tergelincir sampai gelap malam dan (dirikanlah pula shalat) subuh. Sesunggubnya shalat subub itu disaksikean (oleh malaikat) 78. dan pada sebahagian malam hari bersembahyang tahajudlah kamu sebagai suatu ibadah tambahan bagimu; Mudah-mudahan Tuban-mu mengangkat kamu ke tempat yang Terpuji. 79"

Jika di dalam matan hadis Ibnu Majah disunnahkan menghidupkan malam nishfu Sya'ban dengan ibadah sholat, maka sesungguhnya Allah SWT telah memerintahkan untuk menyembah kepada-Nya di waktu hamba lain pada terlelap sebagai ibadah tambahan dan Allah pun tidak mengkhususkan pada suatu malam apapun, namun pada sebagian malam hari atau di tiap tengah malam. Tujuan dari ibadah ini pun tidaklah main-main yaitu mendapatkan derajat yang terpuji dihadapan Allah.Menurut penafsiran Quraish Shihab, makna maqamam mahmudah adalah kebangkitan terpuji atau tempat terpuji bagi Nabi Muhammad SAW sehingga semua makhluk memuji beliau. Dan tempat terpuji inilah yang disebut dengan syafaat terbesar Nabi Muhammad SAW pada hari kebangkitan. ${ }^{62}$

Kandungan matan yang berikutnya ialah berdo'a, bila dikonfirmasi dengan ayat suci al-Qur'an, maka didapati ayat yang menjelaskan bagaimana seorang hamba harus selalu meminta atau berdo'a kepada Allah dan Allah pasti akan menjawabnya. Ayat tersebut terdapat pada surat al-Baqoroh ayat 186 yaitu:

${ }^{62}$ M. Quraish Shihab, Tafsir al-Mishbab; Pesan, Kesan dan Keserasian al-Qur'an, Vol. 7 (Jakarta: Lentera Hati, 2002), 528 


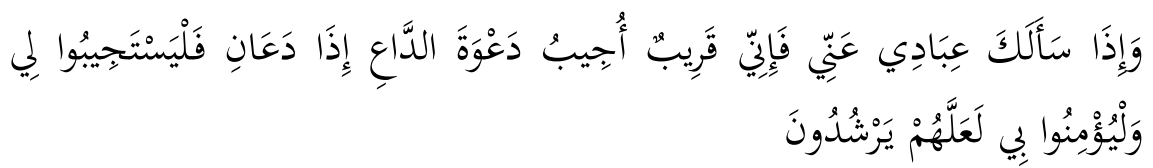

Artinya: ... dan apabila hamba-hamba-Ku bertanya kepadamu tentang Aku, Maka (jawablab), babwasanya aku adalab dekat. aku mengabulkan permohonan orang yang berdoa apabila ia memohon kepada-Ku, Maka hendaklah mereka itu memenubi (segala perintah-Ku) dan hendaklah mereka beriman kepada-Ku, agar mereka selalu berada dalam kebenaran.

Menurut penafsiran Sayyid Quthb bahwa ayat diatas merupakan ayat yang sangat mengagumkan karena penuh dengan kasih sayang, hal ini dikuatkan dengan lantunan ayat yang diawali dengan pernyataan Allah bahwa 'Aku adalah dekat' dan 'Aku akean mengabulkan permohonan orang yang berdo'a apabila ia memohon kepada-Ku'. Di bawah naungan kasih sayang ini Allah mengarahkan Hamba-hamba-Nya kepada jalan yang mustaqim agar selalu mengikuti seluruh perintah-Nya dan menjauhi segala larangan-Nya. ${ }^{63}$ Oleh karena itu, berdo'a kepada Allah tidaklah hanya dikhususkan di malam nishfu' sya'ban belaka melainkan dimana dan kapan pun kita berada, karena Allah mendengarkan apa permohonan dan permintaan hamba-Nya.

\section{b. Konfirmasi dengan hadis lain}

Pada aspek kedua ini, Al-Ghazali menyatakan bahwa untuk mengetahui sebuah kandungan hadis maka perlu dikonfirmasi terlebih dahulu dengan hadis-hadis lain yang sanadnya lebih shahih, di dalam kitabnya al-Ghazali mengatakan sebagai berikut:

Hadis-hadis seperti ini, ketika diamati dengan seksama, jelas berlawanan dengan hadis-hadis lainnya yang sanad dan matannya lebih sahih, dan juga berlawanan dengan logika al-Qur'an yang menjadikan jihad sebagai rukun penting guna mengawal iman dan segala bagian serta peraturannya. ${ }^{64}$

Isi matan hadis yang diriwayatkan oleh Ibnu Majah ini berkenaan dengan ibadah puasa di hari nishfu Sya'ban atau tanggal 15 di bulan Sya'ban, puasa di bulan Sya'ban sebenarnya telah dijelaskan oleh banyak hadis yang lebih shahih derajatnya daripada hadis yang diriwayatkan oleh Ibnu Majah. Namun Hadis-hadis tersebut tidak menyebutkan dikhususkan berpuasa di

${ }^{63}$ Syahid Sayyid Quthb, Fi Zhilalil Qur'an, Terj. As'ad Yasin dkk., Tafsir fi Zhilalil Qur'an di bawab Naungan al-Qur'an Jilid 1-10, (Jakarta: Gema Insani Press, 2000), 206

${ }^{64}$ al-Ghazali, as-Sunnah an-Nabawiyah...., 142 
pertengahan bulan Sya'ban tapi berpuasa di bulan Sya'ban. Hadis-hadis tersebut ialah hadis Bukhori:

$$
\begin{aligned}
& \text { حدثنا عبد الله بن يوسف أخبرنا مالك عن أبي النضر عن أبي سلمة عن عائشة }
\end{aligned}
$$

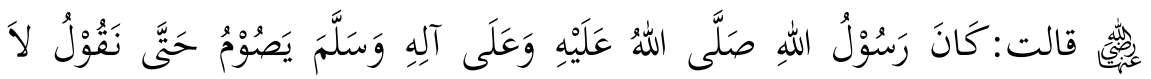

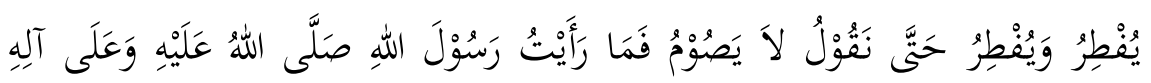

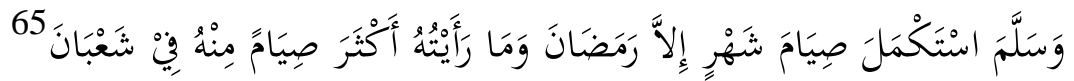

Artinya: "Adalah Rasulullah shollallâbu 'alaibi wa 'alâ âlibi wa sallam berpuasa bingga kami berkata bahwa beliau tidak akan berbuka, dan beliau berbuka bingga kami berkata babwa beliau tidak akan/pernah berpuasa, maka saya tidak pernah melihat Rasulullah shollallâhu 'alaibi wa 'alâ âlihi wa sallam menyempurnakan puasa sebulan selain bulan Ramadhan dan tidaklah saya melihat paling banyaknya beliau berpuasa di bulan Sya'ban."

Selain Bukhori, hadis di atas juga diriwayatkan oleh Muslim no. 1156, Abu Dâud no. 2434, An-Nasâ’i 4/151 dan Ibnu Majah no. 1710. Makna hadis di atas tentu sangat relevan dengan hadis yang diteliti, karena Rasulullah banyak berpuasa sunnah di bulan Sya'ban.

Hadis kedua yang lebih shahih dan relevan isi matannya dengan matan hadis yang diteliti adalah hadis yang diriwayatkan oleh Abu Dâud no. 2336, AtTirmidzy no. 735, An-Nasầi 4/151, 200, Ad-Dârimy 2/29, hadisnya sebagai berikut:

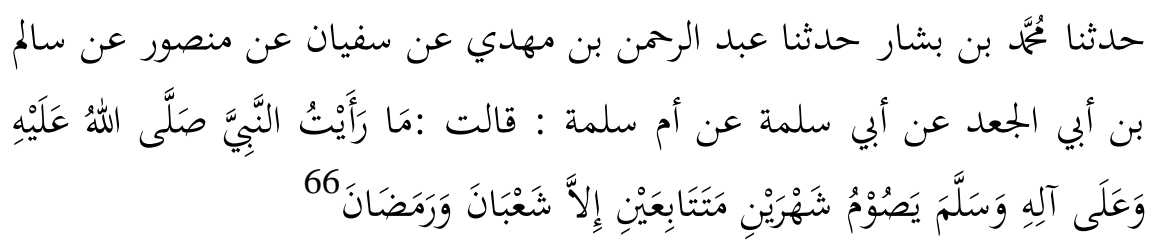

Artinya: "Saya tidak pernah melihat Nabi shollallâhu 'alaibi wa 'alâ âlibi wa sallam berpuasa dua bulan berturut-turut kecuali pada Sya'ban dan Ramadhan."

Makna matan hadis di atas sama dengan hadis pertama, dikarenakan Nabi Muhammad SAW banyak berpuasa sunnah di bulan Sya'ban walaupun

\footnotetext{
${ }^{65}$ Shahih Bukhori, Bab Shaum Sya'ban, No. Hadis 1868 (Maktabah Syamilah)

${ }^{66}$ Sunan at-Tirmidzi, Bab Shaum, No Hadis 736 (Maktabah Syamilab)
} 
secara bahasa disebutkan sebulan penuh akan tetapi pada tradisi Arab jika seseorang banyak berpuasa sunnah dalam satu bulan tertentu hal itu bermakna ia berpuasa satu bulan penuh.

Hadis ketiga yang lebih shahih dari matan hadis yang diteliti adalah hadis yang diriwayatkan oleh Ahmad 5/201, Ibnu Abu Syaibah 2/347, AnNasâ'i 4/201, Ath-Thahawy dalam Syarah Ma'âny Al-Atsâr 2/82, Al-Baihaqy dalam Syu'bul Imân 3/377 dan Abu Nu'aim dalam Al-Hilyah 9/18. Dan menurut syaikh al-Albani sanad hadis ini adalah hasan. Makna matan hadis di atas terlihat jelas bahwa Nabi berpuasa di bulan Sya'ban.

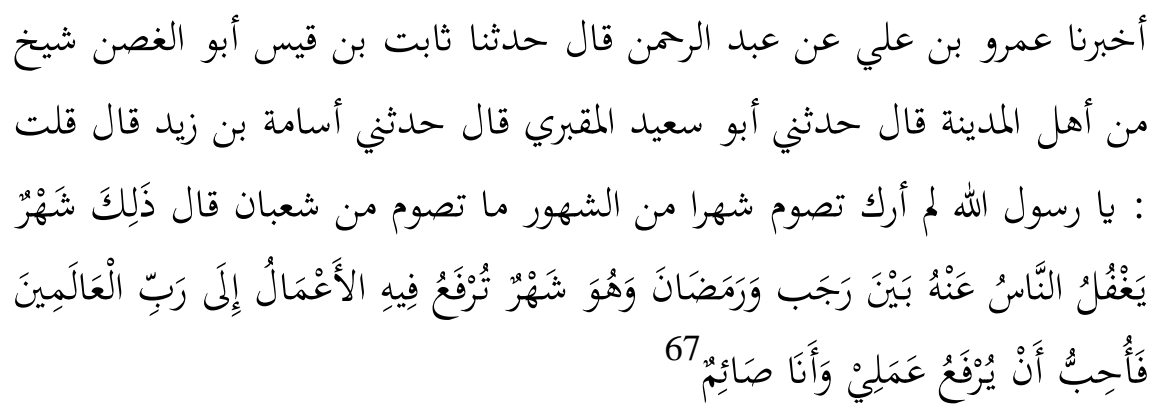

Artinya: "Itu adalab bulan antara Rajab dan Ramadhan yang manusia lalai darinya. Dan ia adalah bulan yang padanya segala amalan akan diangkat kepada Rabbul 'Alamin. Maka saya senang amalanku diangkat sementara saya sedang berpuasa."

\section{c. Konfirmasi dengan fakta sejarah}

Pada aspek ketiga, al-Ghazali menekankan untuk dikonfirmasi dengan fakta sejarah, sehingga kandungan hadis dapat diketahui dengan jelas. Di dalam kitabnya al-Ghazali menyatakan:

Hadis-hadis abad harus dimundurkan apabila berhadapan dengan nash

Qur'ani atau kebenaran ilmiah ataupun fakta historis. Atau, sebagaimana dinyatakan oleh para pengikut madzhab Maliki, harus mundur di hadapan praktek amalan penduduk Madinah. Atau, di hadapan qiyas qath'i, sebagaimana dinyatakan oleh para pengikut mazhab Hanafi. ${ }^{68}$

Berdasarkan fakta sejarah bahwa di zaman Rasulullah SAW., dan para sahabat tidak pernah menghidupkan ibadah di malam nisfhu Sya'ban khususnya secara berjamaah. Dan yang memulai menghidupkan ibadah

\footnotetext{
${ }^{67}$ Sunan Nasa'I, bab Syiam, No hadis 2357 (maktabah syamilab)

68 al-Ghazali, as-Sunnah an-Nabawiyah...., 209
} 
tersebut yaitu ulama-ulama ahli Syam yang mereka pun berbeda pendapat, di dalam kitab Lathaiful Ma'arif diceritakan bahwa:

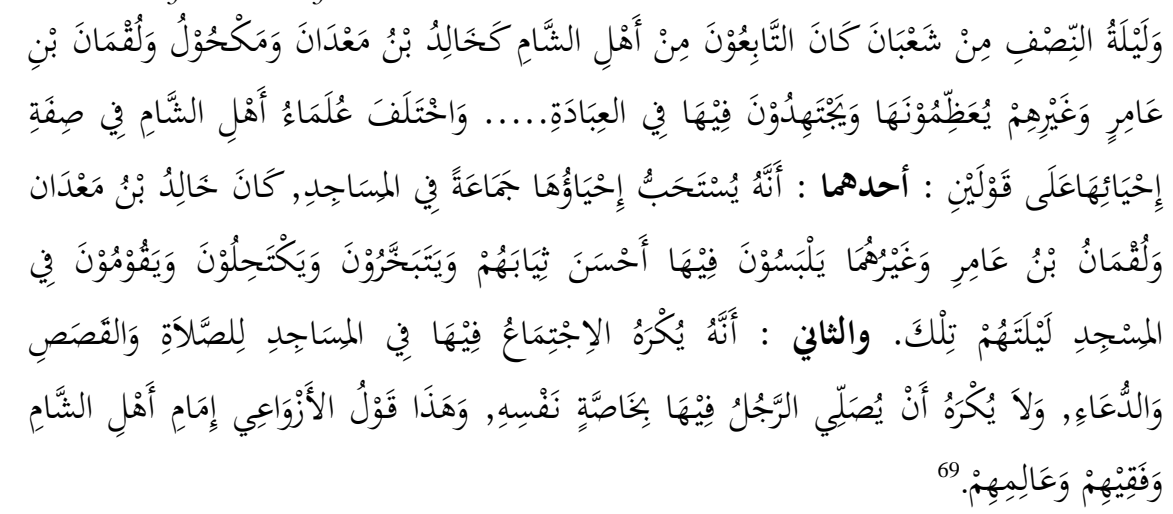

Artinya:Dan pada malam nishfu Sya'ban para Tabi’in dari abli Syam seperti Khalid ibn Ma'dan dan Makbul dan Lukman ibn Amir dan lainnya, pernah mengagungkan dan berijtihad untuk beribadah di malam nisfhu Sya'ban.... terdapat perbedaan ulama abli Syam dalam menghidupkan malam nisfhu Sya'ban yaitu, pertama: sesunggubnya dibolebkan menghidupkan malam nisfhu Sya'ban secara berjamaah di masjid, dabulu Khalid ibn Ma'dan dan Lukman ibn Amir memperingati malam nisfbu Sya'ban dengan memakai pakaian paling baru dan mewah, membakar menyan dan memakai celak serta bangun malam untuk menjalankan sholat malam di Masjid. Kedua: dimakrubkan untuk berkumpul di dalam masjid untuk sholat, bercerita dan berdoa. Dan tidak dimakrubkan seseorang beribadah sholat secara pribadi, ini pendapat Azwa'iy Imam abli Syam.

\section{d. Konfirmasi dengan kebenaran ilmiah}

Selanjutnya, menurut al-Ghazali kandungan hadis juga harus dikonfirmasi dengan kebenaran ilmiah yaitu hasil atau temuan ilmiah yang dilakukan oleh ilmuwan-ilmuwan seperti temuan ilmiah dalam gerakan sholat dibawah ini:

Di dalam tulisannya Abdullah disebutkan : Gerakan shalat menurut para ilmuwan dan dokter salah satu terbaik untuk menyembuhkan rematik (terutama untuk tulang punggung), yang disebabkan oleh

\footnotetext{
${ }^{69}$ Imam al-Hafidz Zainuddin Abi Faroji Abdurrahman ibn Ahmad ibn Rojab al-Khobali adDimasyqi, Lathaiful Ma'arif: Fima Miwasmi al'aami mina al-Wadzoifi, (Bairut: Daru ibn Katsir, 1999), 263
} 
ketidakseimbangan otot. Berdasarkan saran dokter tidak ada solusi yang berbaik untuk menghindari rematik sejak dini dengan melaksanakan sholat 5 waktu secara konsisten dan juga banyak melakukan gerak untuk meminimalisir kemungkinan penyakit tulang punggung, memanfaatkan kesempatan sebaik mungkin mengembalikan keseimbangan pada persendian dan otot tubuh, dan otot tubuh, dan hendaknya hal ini tetap dilaksanakan walaupun ada kerusakan tulang atau setelah penggunaan gips. Dapat disimpulkan bahwa gerakan sholat adalah jenis gerakan terbaik yang selaras dengan saran dokter dan mampu mengembalikan fungsi otot dengan baik, gerakan yang dimaksud diantaranya gerakan rukuk, berdiri tegak, sujud dalam waktu yang lama dan dilakukan berulang. ${ }^{70}$

Berdasarkan temuan ilmiah ini, bahwa gerakan di dalam sholat sangat menyehatkan. Oleh karena bila ingin menghidupkan malam nisfhu Sya'ban dengan beribadah sholat dalam pandangan ilmiah tidak ada masalah, karena dengan sering beribadah sholat maka kesehatan otot tulang semakin terjaga.

\section{Living Sunnah : Tradisi Menghidupkan Malam Nishfu Sya'ban}

Living sunnah merupakan sunnah atau hadis yang hidup di tengahtengah masyarakat akibat adanya keinginan masyarakat mengaplikasikan sunnah atau hadis dalam konteks sosial, budaya, politik, ekonomi dan hukum. Dengan demikian living sunnah ialah tulisan, bacaan dan praktik yang diaplikasikan oleh masyarakat di tengah-tengah kehidupan sebagai tindakan mengaktualisasikan isi sunnah atau hadis Nabi. ${ }^{71}$

Saat sunnah diartikan sebagai sebuah praktik yang disepekati bersama, maka itulah yang dinamakan living sunnah atau sunnah yang hidup di tengahtengah masyarakat. Sebenarnya Sunnah relatif identik dengan ijma' kaum Muslimin dan ke dalamnya termasuk pula ijtihad dari para ulama generasi awal yang ahli dan tokoh-tokoh politik di dalam aktivitasnya. Dengan demikian, "sunnah yang hidup" adalah sunnahNabi yang secara bebas ditafsirkan oleh para ulama, penguasa dan hakim sesuai dengan situasi yang mereka hadapi. ${ }^{72}$

\footnotetext{
${ }^{70}$ Deden Suparman, Pembelajaran Ibadah Shalat dalam Perspektif Psikis dan Medis, Jurnal ISTEK (Jurnal Kajian Islam, Sains dan Teknologi), Vol. IX No. 2, 2015, Fakultas Sains dan Teknologi UIN Sunan Gunung Djati Bandung, 66

${ }^{71}$ M. Alfatih Suryadilaga, Metodologi Penelitian Living Qur'an dan Hadis (Yogyakarta: Teras, 2007), 106

${ }^{72}$ M. Alfatih Suryadilaga dkk, Metodologi Penelitian Hadis (Yogyakarta: PokjaAkademik UIN Sunan Kalijaga, 2006), 193
} 
Pada penelitian ini, tradisi bacaan lebih dominan dibahas serta dikaji karena konteks penelitian living sunnah nya terdapat dalam tataran bacaan/amalan yang dihidupkan saat datangnya nishfu Sya'ban. Walaupun tradisi praktek juga bisa diamati dan ditanyakan kepada subyek penelitian yaitu para mahasiswa.

\section{Sumber Data}

Sumber data dalam penelitian adalah subyek dari mana data diperoleh, jika peneliti menggunakan teknik wawancara maka sumber datanya ialah responden, jika peneliti menggunakan teknik observasi maka sumber datanya ialah benda, gerak atau proses sesuatu, sedangkan jika peneliti menggunakan dokumentasi maka sumber datanya ialah catatan dan isi catatan sebagai subyek penelitian atau variabel penelitian. ${ }^{73} \mathrm{Pada}$ penelitian living sunnah ini, peneliti memilih responden sebagai sumber data penelitian dengan metode kuisoner online. Sedangkan responden yang dipilih meliputi mahasiswa-mahasiswi yang kuliah di Perguruan Tinggi se Kabupaten Jember. Dan lingkup perguruan tinggi yang disebar kuisoner ini hanya tiga perguruan tinggi saja yaitu Institut Agama Islam Negeri (IAIN) Jember, Universitas Negeri Jember dan Politeknik Negeri Jember.

Penyajian data penelitian living sunnah/hadis tentang amalan di malam nishfu sya'ban diperoleh dari hasil sebaran kuisoner online dengan beberapa responden dari mahasiswa-mahasiswi yang kuliah di perguruan tinggi se kabupaten Jember. Dari ketiga perguruan tinggi tersebut ada 18 responden, hampir $80 \%$ berasal dari kampus IAIN Jember, sisanya yaitu 20\% dari Universitas Negeri Jember dan Politeknik Negeri Jember. Dari 18 responden tersebut $59,1 \%$ ada di semester enam, sisanya $27,3 \%$ di semester empat dan $9 \%$ di semester delapan serta 4,5\% di semester dua. Sedangkan asal sekolah ke 18 responden tersebut ialah $68,2 \%$ berasal dari SMA/SMK, sisanya $22,7 \%$ berasal dari MAN/MA.

Pada sebaran kuisoner online, peneliti membagi dua tema pertanyaan berkenaan dengan amalan-amalan di malam nishfu Sya'ban yang menjadi tradisi di kalangan mahasiswa. Dua tema tersebut sebagai berikut:

\section{Amalan di Malam Nishfu Sya'ban}

a. Apa amalan yang saudara lakukan untuk menghidupkan malam nisfhu Sya'ban?

\footnotetext{
${ }^{73}$ Suharsimi Arikunto, Prosedur Penelitian: Suatu Pendekatan Praktik, Edisi Revisi VI, (Jakarta: PT Rineka Cipta, Cet. XIII, 2006), 129
} 
Hampir 70\% responden menjawab dengan membaca yasin 3x atau dengan bahasa lain membaca al-Qur'an atau tadarusan. Ada lagi yang menambahkan dengan sholat sunnah 2 rakaat, membaca sholawat, memperbanyak istighfar, berdoa dan berpuasa. ${ }^{74}$

b. Apa motivasi saudara menghidupkan malam nishfu Sya'ban?

Banyak responden menjawab motivasi mereka menghidupkan malam nishfu Sya'ban hanyalah untuk memohon ampunan dan perlindungan dari Allah SWT. Namun ada jawaban lain dari responden terkait motivasi mereka diantaranya ialah menjalankan sunnah Rasulullah, mendapatkan hidup yang lebih barokah serta mendekatkan diri kepada Allah SWT. ${ }^{75}$

c. Dari mana saudara mengetahui amalan-amalan di malam nishfu Sya'ban?

Lebih dari $80 \%$ responden menjawab mereka mendapatkan info amalan-amalan tersebut dari guru mereka (Ustadz/Kiai/Dosen). Namun ada juga yang menjawab mendapatkan info dari Buku, Group Whatsapp, Masyarakat, Snapgram teman. ${ }^{76}$

\section{Dasar Hukum Amalan Di Malam Nishfu Sya'ban}

a. Apakakah saudara mengetahui dalil/dasar hukum amalan di malam nishfu Sya'ban?

Berdasarkan data yang peneliti peroleh ada sekitar 54,5\% responden tidak mengetahui dalil atau dasar hukum menghidupkan malam nishfu Sya'ban. Dan 45,5\% mengetahui dasar hukumnya.

b. Jika dalil/dasar hukumnya lemah, apakah saudara tetap menjalankan amalan di malam nisfhu Sya'ban?

Berdasarkan data yang peneliti peroleh bahwa 63,6\% responden menjawab ya mereka tetap akan menghidupkan malam nishfu Sya'ban walaupun dalilnya lemah. Sekitar 22,7\% menjawab tidak dan 13,6\% menjawab mungkin.

\footnotetext{
${ }^{74}$ Diolah dari sumber data kuisoner online peneliti

${ }^{75}$ Diolah dari sumber data kuisoner online peneliti

${ }^{76}$ Diolah dari sumber data kuisoner online peneliti
} 
Berdasarkan data yang telah diperoleh, maka dalam sub hasil penelitian ini peneliti berusaha menganalisa apa yang telah terjadi sesuai fakta di masyarakat berkenaan dengan amalan di malam nishfu Sya'ban. Jika dirujuk kembali apa yang dijawab oleh Mahasiswa-mahasiswa di atas, maka dapat disimpulkan bahwa amalan tersebut telah mereka amalkan sejak lama walaupun tidak mengetahui dasar hukumnya, dan walaupun sudah mengetahui mereka tetap mengamalkannya karena hal itu tidak bertentangan dengan ajaran agama Islam. membaca yasin, berpuasa merupakan perbuatan yang dianjurkan oleh agama.

Menurut teori atau dasar hukum yang ada bahwa mengkhususkan amalan sesuatu pada waktu malam nishfu Sya'ban merupakan perbuatan yang tidak ada di dalam agama, karena dalil yang menerangkan seperti itu ternyata palsu/maudhu' disebabkan satu diantara perawinya dikategorikan pemalsu hadis. Pada kedua hal di atas antara kenyataan di lapangan dan dalil yang ada sangat bertentangan, sehingga peneliti memberikan penilaian bahwa hadis lemah/palsu yang berkaitan dengan amalan di malam nishfu Sya'ban ini tetap hidup di tengah-tengah masyarakat hingga saat ini.

\section{Simpulan}

Berdasarkan penelitian terhadap kualitas sanad, kandungan matan dan living sunnah terhadap hadis yang berkenaan dengan amalan di malam nishfu Sya'ban tersebut, peneliti menemukan/menyimpulkan bahwa :

1. Sanad hadis yang diriwayatkan oleh Ibnu Majah dari rawi Ali ibn Abi Thalib tersebut bersambung, tapi satu diantara perawi dikategorikan sebagai pemalsu hadis, sehingga hadis tersebut tidak dapat dijadikan hujjah, I'tibar dan tidak boleh dicatat. Hadis seperti ini disebut dengan hadis mau'dhu'atau hadis palsu.

2. Berdasarkan kajian kandungan matan hadis tersebut secara implisit tidak bertentangan dengan ayat-ayat suci al-Qur'an serta hadis-hadis yang lebih shahih. Dan berdasarkan fakta sejarah dan kebenaran ilmiah pun amalanamalan di malam nisyfu Sya'ban sebagian ulama membolehkan menghidupkannya. Namun secara eksplisit matan tersebut tidak ada keterangan di dalam al-Qur'an maupun hadis dikarenakan mengkhususkan amalan pada malam nishfu Sya'ban.

Berdasarkan penelitian di kalangan mahasiswa Perguruan Tinggi se Kabupaten Jember, didapati bahwa amalan-amalan tersebut masih tetap eksis dipraktikkan oleh mereka, karena hal itu menurut mahasiswa merupakan 
perbuatan baik untuk mendekatkan diri kepada Allah dan tidak melanggar aturan agama. Jadi hadis tersebut tetap hidup di tengah-tengah masyarakat.

\section{Daftar Pustaka}

Abu 'Alfah, Roid Shobrah. Syurub Sunan Ibnu Majah, Juг I, Aman: Baitul Afkar Ad-Dauliyah, 2007

ad-Dimasyqi, Imam al-Hafidz Zainuddin Abi Faroji Abdurrahman ibn Ahmad ibn Rojab al-Khobali, Lathaiful Ma'arif: Fima Miwasmi al'aami mina alWadzoifi, Bairut: Daru ibn Katsir, 1999

al-Ghazali, Muhammad, as-Sunnah an-Nabawiyah Baina Abli al-Figh wa Abli albadi, (Studi Kritis Hadis Nabi SAW., Antara Pemahaman Tekstual dan Kontekstual, Terj. Muhammad al-Baqir), Bandung: Mizan, Cet. II, 1992 al-Hadi, Abu Muhammad Abd al-Hadi bin Abd al-Qadir bin.Turuq Takhrij Hadis Rasulillah, Mesir: Dar al-Fikr, t.th.

Arikunto,Suharsimi.Prosedur Penelitian: Suatu Pendekatan Praktik, Edisi Revisi VI, Jakarta: PT Rineka Cipta, Cet. XIII, 2006

A.J,Wensinck. al-Mu'jam al-Mufahras li Alfadz al-Hadis al-Nabawi, Leiden: E.J. Brill, 1936

al-Mizzi,Jamal al-Din Abi al-Hujjaj Yusuf.Tahdrib al-Kamal fi Asma' al-Rijal, Jilid 27, Beirut: Muassasah al-Risalah, 1992

6, Beirut: Muassasah al-Risalah, 1992

,Tahdzib al-Kamal fi Asma' al-Rijal, Jilid

,Tabdrib al-Kamal fi Asma' al-Rijal, Jilid

18, Beirut: Muassasah al-Risalah, 1992

33, Beirut: Muassasah al-Risalah, 1992

Tahd₹ৃib al-Kamal fi Asma' al-Rijal, Jilid

2, Beirut: Muassasah al-Risalah, 1992

Tabdzib al-Kamal fi Asma' al-Rijal, Jilid

, Tahdrib al-Kamal fi Asma' al-Rijal, Jilid

28, Beirut: Muassasah al-Risalah, 1992

, Tabdzib al-Kamal fi Asma' al-Rijal, Jilid

14, Beirut: Muassasah al-Risalah, 1992

20, Beirut: Muassasah al-Risalah, 1992

Tabdrib al-Kamal fi Asma' al-Rijal, Jilid

asy-Syafi'i, Al-Hafidz Abi Fadhil Ahmad bin Ali bin Hajar Syihab ad-Din al'Asqalaani.Tahzib at-Tabz̧ib, Juz 1,Bairut: Muassah ar-Risalah, 1996 
Muassah ar-Risalah, 1996

, Tabzib at-Tabə̧ib, Ju₹, 2,Bairut:

Muassah ar-Risalah, 1996

, Tabzib at-Tahæbib, Juz, 3,Bairut:

Muassah ar-Risalah, 1996

, Tabzib at-Tahæbib, Ju₹, 4,Bairut:

Ismail, M. Syuhudi. Metodologi Penelitian Hadis Nabi, Cet. I; Jakarta: Bulan Bintang, 1993

Majah, Ibn. Sunan Ibnu Majah, Kairo: Dar Al-Hadis, t.th

Quthb, Syahid Sayyid. Fi Zhilalil Qur'an, Terj. As'ad Yasin dkk.,Tafsir fi Zhilalil Qur'an di bawah Naungan al-Qur'an Jilid 1-10, Jakarta: Gema Insani Press, 2000

Shihab, M. Quraish. Tafsir al-Mishbah; Pesan, Kesan dan Keserasian al-Qur'an, Vol. 7,Jakarta: Lentera Hati, 2002

Suparman, Deden, Pembelajaran Ibadah Shalat dalam Perspektif Psikis dan Medis, Jurnal ISTEK (Jurnal Kajian Islam, Sains dan Teknologi), Vol. IX No. 2, 2015, Fakultas Sains dan Teknologi UIN Sunan Gunung Djati Bandung

Suryadilaga, M. Alfatih, Metodologi Penelitian Living Qur'an dan Hadis Yogyakarta: Teras, 2007

Suryadilaga, M. Alfatih, dkk, Metodologi Penelitian Hadis Yogyakarta: Pokja Akademik UIN Sunan Kalijaga, 2006

Tahhan, Mahmud. Ushul al-Takbrij wa Dirasat al-Asanid, Beirut: al-Matba'ah alArabiyyah, 1978

www.islamweb.net

Shahih Bukhori, Bab Shaum Sya'ban, No. Hadis 1868 (Maktabah Syamilah)

Sunan at-Tirmidzi, Bab Shaum, No Hadis 736 (Maktabah Syamilab)

Sunan Nasa'I, bab Syiam, No hadis 2357 (maktabah syamilah) 